Lewis Doney

\title{
4 Bronze Temple Bells from the Tibetan Imperial Period: Buddhist Material Culture in Context
}

\section{Introduction}

From at least the beginning of the Common Era, bells or gongs have formed a part of daily ritual practice and rites of passage in the Buddhist temples and monasteries of South Asia. Yet it is in the countries to which Buddhism spread that we find the most evidence of large temple bells bearing epigraphy in both an artistic and literary register. ${ }^{1}$ Chinese donors of both the Buddhist and Daoist traditions commissioned or supported the casting of such bells, and the technology spread to Inner Asia, Korea, and Japan from at least the seventh century, to Tibet from about the eighth century, and to Southeast Asia from perhaps the tenth century CE. Temple bells were used to mark time, raise alarm, and, according to their written inscriptions, emit spiritual sounds into the universe. Such epigraphy, either inscribed or cast into the bells, may praise the quality of their peal, record the sponsorship of the bell's founding, or proclaim the religion it represents. Later indigenous literature and folk stories in these lands then creatively recast the bells to serve new narrative purposes. However, early examples of this difficult, costly, and prestigious art form are now rare. The undoubtedly many examples that once existed in the second half of the first millennium have either broken, been destroyed, or been melted down at some point over the intervening centuries. Thus, those we do possess provide precious data regarding the early form, technology, and use of large temple bells in Buddhist Asia.

In Tibet, a handful of bronze temple bells have been recorded whose epigraphy suggests that they were created during Tibet's imperial period (ca. 600-850 CE) their inscriptions either mentioning Tibetan emperors or being written in the Old

1 A good general introduction to this theme is Percival Price, Bells and Man (Oxford: Oxford University Press, 1983), 9-13.

Note: This article was researched with funding from the European Research Council, while employed by the project "Beyond Boundaries: Religion, Region, Language and the State" (ERC Synergy Project 609823 ASIA).

○ Open Access. (C) 2020 Lewis Doney, published by De Gruyter. (cc) BY-NC-ND This work is licensed under a Creative Commons Attribution-NonCommercial-NoDerivatives 4.0 International License.

https://doi.org/10.1515/9783110557176-005 
Tibetan language of that period. This marks them out as among the earliest examples of cast temple bells from Asia and precious sources of knowledge regarding the movement of material culture across Buddhist Asia at this time. However, the scholars who brought these bells to wider attention or worked on deciphering their epigraphy - Giuseppe Tucci, Hugh Edward Richardson, and Li Fang-Kuei and W. South Coblin - focused almost exclusively on the content of the inscriptions as texts of historical interest. In brief opening remarks, these men describe the bells as "shaped like the Chinese bells," "of Chinese pattern," and "Chinese-style," respectively. ${ }^{2}$ However, one may ask, what does that really mean? Is there one "Chinese" type or design for bells? In what ways and to what extent do the Tibetan exemplars adhere to this/these form(s)? This chapter focuses on art-historical aspects of Tibetan imperial temple bells, attempting to answer these questions by comparing the bells with the few examples extant in Buddhist Asia.

Over the course of this chapter, it will become clear that Chinese temple bells of the late first millennium display a variety of designs rather than a homogeneity. Their artisans or patrons could choose a simpler or more ornate style and whether or not to include epigraphy; these aesthetic trends spread to surrounding states like Korea, Japan, and Tibet, which each followed their own styles and could blend external influence with indigenous bell traditions at will. It will be shown that the bronze temple bells of the Tibetan imperial period resemble the simpler contemporaneous Chinese and later Japanese models rather than the floral design of some other Chinese temple bells or the complex religious and ritual imagery of Korean examples of a similar antiquity. Beyond the design of the main bodies of Chinese temple bells, the form is split into two types, the more typical flat-bottomed variety and the rarer sort with scalloped bases (sometimes referred to as "lotus-petalled"). The flat-based bell predominates in Asia, but the scalloped model seems to have influenced other countries' forms of bell to a limited extent. It will be seen that no extant antique Tibetan temple bells are flat bottomed. Their scalloping is generally rounded, but can also tend toward the more pointed nadirs found in eleventh-century Chinese bells. This is in contrast to the flatter concave design of some important early Korean Buddhist bells or the low relief convex scallops seen (with exceptions) in Japan. It is hoped that this discussion will inspire further dialogue between Tibetan studies and campanology for the benefit of both fields.

2 Giuseppe Tucci, The Tombs of the Tibetan Kings (Roma: Is.M.E.O, 1950), 69; Hugh Edward Richardson, "A Ninth Century Inscription from Rkon po," Journal of the Royal Asiatic Society 3-4 (1954): 166; Li Fang-Kuei and W. South Coblin, A Study of the Old Tibetan Inscriptions (Taipei: Institute of History and Philology, Academica Sinica, 1987), 332. 


\section{Main Types of Temple Bell}

The "classic" Chinese temple bell design in the (mostly Korean) works on this subject includes both flat-bottomed and "scallop-edged" forms. ${ }^{3}$ Figure 1 provides representations of four types of bell, using the following as models (clockwise from top right):

1. the earliest extant Chinese bell, cast in $575 \mathrm{CE}$, lacking measurements (but $39.1 \mathrm{~cm}$ high and $21 \mathrm{~cm}$ wide; see below);

2. an early Japanese temple bell, perhaps the Kanzeon-ji (観世音寺) Bell of 698;

3. a Chinese bell probably dating from the tenth century; and

4. the Korean Sangwŏnsa (상원사) Bell, founded in 725 .

As Figure 1 makes clear, East Asian temple bells display certain family resemblances. For example, they share dragon-shaped supporting loops at the tops, from which they are hung to be hit by a mallet or other object from outside. This is in contrast to clapper bells of the European tradition and smaller Asian bells, which contain a free-swinging object that hits the inside wall of the bell. Another similarity between the pictured bells is the use of lotuses as design motifs. These are depicted either as open-faced whole lotuses used as the striking points on the outside wall (in the center of bells 1 and 2, and displayed in profile on the left and right of bell 4) or as petals on decorative bands (depicted in bells 3 and 4, but also found in the others).

Despite such shared features, these bells also display their own distinctive forms or characteristics. Three of the four bells are convex in aspect, less familiar to people in the West than the concave European bell shape from which we take the term "bell curve." Bell 3, though, displays a lightly concave outline. This bell, the second of the Chinese exemplars and the youngest bell depicted in Figure 1, also lacks the flat bottom of the other bells. Instead, it exhibits an undulating wave curvature, almost like a sine wave, traveling all around its rim, resembling the convex "scalloped edge" of a piece of lace. From this small sample, it is clear that Chinese temple bells evidently came in both a flatbottomed and scallop-rimmed form from an early period, around the second half of the first millennium $\mathrm{CE}^{4}$

3 Yŏm Yŏng-ha, Han'guk Ǔi Chong: Korean Bell (Seoul: Sŏul Taehakkyo Ch’ulp’anbu, 1991), $3-10$.

4 In using the term "scalloped" to refer to the rim of this type of bell, I am following the usage found in Price, Bells and Man. 


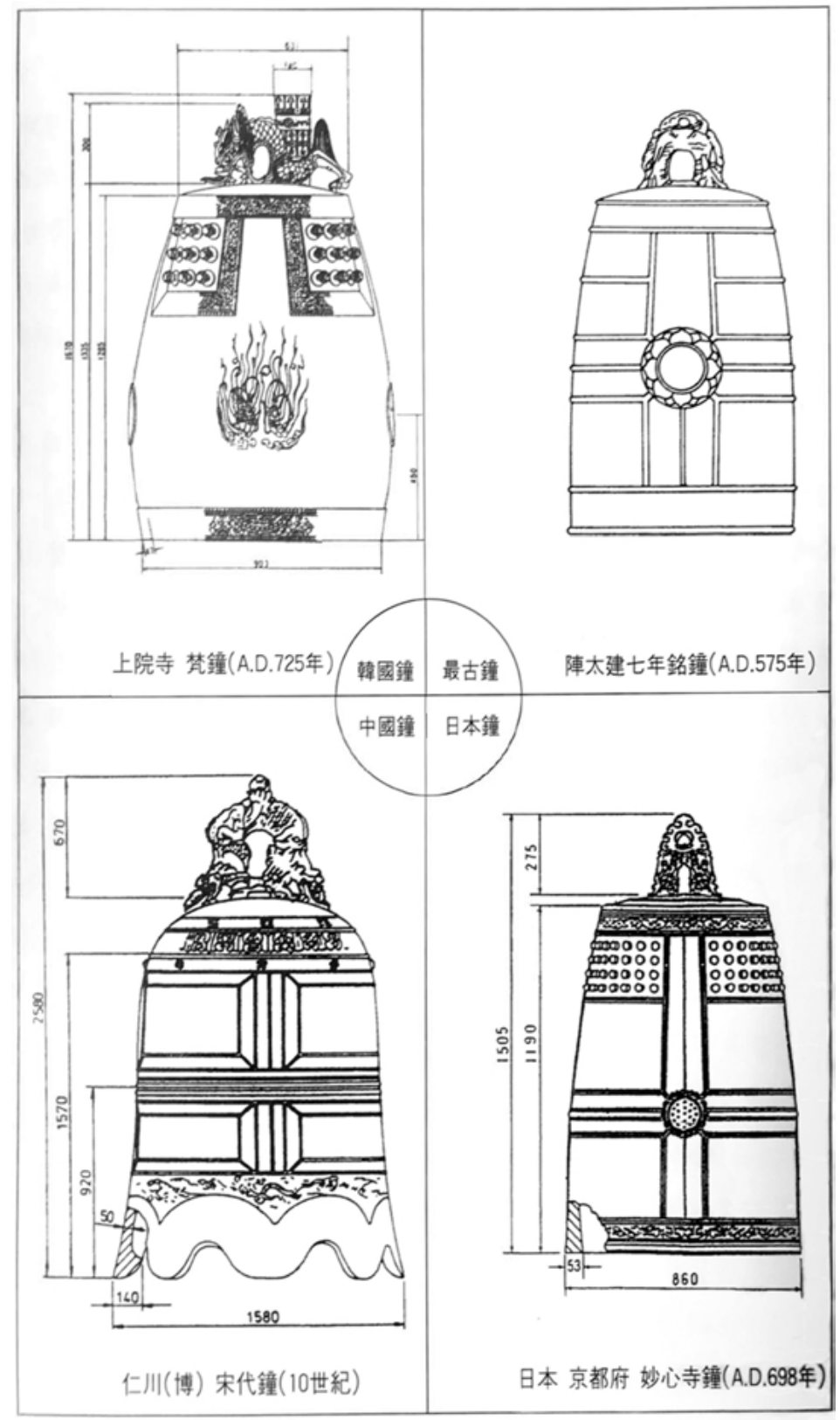

Figure 1: Diagram of four types of East Asian bell in Kungnip Kyŏngju Pangmulgwan, Sŏngdŏk Taewang Sinjong (Gyeongju: Kungnip Kyŏngju Pangmulgwan, 1999), vol. 1, 211. 
The scallop-rimmed type of temple bell should be particularly interesting to scholars of Tibetan studies, since it is the only form represented among the extant candidates for Tibetan imperial-period bells. These five candidates display Old Tibetan epigraphy and other indications suggestive of being used in an imperial context. A heuristic distinction can be made between concave, convex, and "undulating curve" scalloping on the base of Tibetan bells that each connects them with only some of their East Asian contemporaries and antecedents. The concave type links Tibetan temple bells with a few extant Korean examples; the convex type is found in an old Japanese temple bell; and the undulating wave lies somewhere in the middle. Other East Asian temple bells have flat bottoms, a feature not found in any of the Tibetan examples discovered so far. Given the scarcity of examples of early temple bells across Buddhist Asia, a proper analysis of the bronze temple bells dating from the Tibetan imperial period should not only help to illuminate the Tibetan empire's relation to this aspect of wider East Asian material culture, but also shed light on the choices made by artisans and patrons further afield who helped to uphold the tradition of large bell casting in contemporaneous China, Japan, Korea, Japan, and even perhaps northern Vietnam.

\title{
3 East Asia
}

As the above typology makes clear, the study of early Buddhist temple bells focuses on East Asia, specifically comparing Chinese, Korean, and Japanese examples. According to Claudine Salmon, an expert on Asian campanology,

\begin{abstract}
Chinese bells seem to have the longest and most completely documented history. Fanzhong appeared in China soon after Buddhism was introduced there during the Han Dynasty. Since then these bells have been closely linked to temples and to the religious life of the Chinese. Bells of small size, usually hung inside the prayer hall, were struck when Buddhist monks chanted scripture or conducted other rituals. The large bell, like the drum, was sheltered inside a small edifice located in the courtyard in front of the prayer hall. Such bells, differing only slightly in their decoration, made their way into Daoist temples. They also entered the court, where they served to announce various ceremonies. Similar bells were used to mark urban time, especially to sound night watches and to warn the population. ${ }^{5}$
\end{abstract}

5 Claudine Salmon, "Transnational Networks as Reflected in Epigraphy: The Case of Chinese Buddhist Bells in Southeast Asia," in Chinese Overseas: Migration, Research and Documentation, eds. Tan Chee-Beng and Julia Zimmerman (Sha tin, N.T., Hong Kong: Chinese University Press, 2007), 23-24. 
The oldest dated Chinese Buddhist bell (founded in 575) is now kept in the Museum of Nara in Japan. It is a plain, small bell in comparison with the others described below, $39.1 \mathrm{~cm}$ high and $21 \mathrm{~cm}$ in diameter at the mouth, simply decorated with vertical and horizontal ribs converging on a striking point that takes the shape of an eight-petalled lotus. ${ }^{6}$ Its written epigraphy is inscribed on the bell, rather than forming part of the original mould, and simply records the date of its casting, those responsible, and the weight. ${ }^{7}$ The bell is flat mouthed rather than scalloped, and so is of less importance to us here than other, later examples.

Certain surrounding states and dependent regions soon emulated the Chinese model of temple bells, and Salmon identifies one early example in modern-day Vietnam. Southeast Asian Buddhists appear to have relied more on gongs, stone chimes, and sonorous rocks for their timekeeping and rituals. ${ }^{8}$ They perhaps also shared this practice with older Chinese cultural traditions, if they were not influenced by them. However, Vietnam was more deeply Sinicized during the latter part of the first millennium. The bell, founded in 798, possesses a striking point (zhongyue) depicting a lotus with ten petals and epigraphy in Chinese. ${ }^{9}$ Salmon states, "The text of the Sino-Vietnamese bell [inscription], in 41 characters, merely commemorates the day of casting and donation while indicating the weight, and so do the inscriptions on the oldest bell of 575 and that of 748 (except the weight)." ${ }^{10}$ Later bells of southern China and Southeast Asia, including scalloped bells, are described in Salmon's later work on the subject. ${ }^{11}$ She argues that this Sino-Vietnamese bell, "although probably not the first to have been cast in the Protectorate of Annam, may be regarded as a marker of Buddhism and Chineseness in an environment in which the bronze drum cul-

\footnotetext{
6 Claudine Salmon, "Tang-Viet Society as Reflected in a Buddhist Bell Inscription from the Protectorate of Annam (798)," in Guangdong: Archaeology and Early Texts / Archäeologie und frühe Texte (Zhou-Tang), eds. Shing Müller, Thomas O. Höllemann, and Putao Gui, South China and Maritime Asia 13 (Wiesbaden: Harrassowitz, 2004), 197. See also the journal Nihon no bijutsu日本の美術 [Art of Japan] 355 (1995): plate 25.

7 Salmon, “Tang-Viet Society,” 197 and 199.

8 Salmon, "A Tentative Interpretation of the Chinese Inscription (1231) Engraved on a Bronze Gong Recovered in Muara Jambi (Central Sumatra),” Archipel 66 (2003): 91-112. See also Arsenio Nicolas, "Gongs, Bells and Cymbals: The Archaeological Record in Maritime Asia from the Ninth to the Seventeenth Centuries," Yearbook for Traditional Music 41 (2009): 62-93.

9 Salmon, "Tang-Viet Society," 197.

10 Salmon, "Tang-Viet Society," 199.

11 Salmon, "Tang-Viet Society," especially 70-74.
} 
ture was still alive, even if at the end of the eighth century the casting of drums had already declined in the Red River Delta, as compared to what it was during the three first centuries A.D."12

\section{The Sŏngdŏk Bell, Korea}

Korea, toward the end of the Silla period (ca. 57 BCE-935 CE), was another region bordering China to make bell casting their own. A 1976 work on Korean temple bells estimates that 158 were already known to be extant, with the lion's share still present in Korea itself. ${ }^{13}$ Although most postdate the period that interests us here, one of the earliest known examples, after the Sangwŏnsa Bell cast in $725 \mathrm{CE},{ }^{14}$ was cast with a shallowly scalloped bottom. This is the socalled Sŏngdŏk Bell (성덕대왕 신종), founded in 771 (Figure 2). A very large and finely detailed bell, it was cast using the cire-perdue or lost-wax method and is said to embody the last of several attempts at founding it.

The bell was housed for most of its life in the temple of Pongdŏk in Kyŏngju (today's Gyeongju), and so is also named the Kyŏngju Bell. In 1902, H.B. Hulbert stated,

This is the monster bell that for centuries tolled for the opening and shutting of the gates of Kyŏng-ju, or as it was then called, Sŭ-ya-bŭl, from which by contraction is probably derived the modern word Seoul. [...] History says it was cast by King Hyo-jong [=Hyegong (r. 765-780)], the thirty-sixth of the dynasty, 765, that it was originally intended as a monastery bell and was placed at Pong-dŭk Monastery a short distance to the east of the town but that King Chŭn-sun [=Gyeongsun (r. 927-935)?] in his fourth year moved it to its present site. ${ }^{15}$

12 Salmon, “Tang-Viet Society," 27-30.

13 Lee Ho-Kwan, "A Study on the Temple Bell Style in the Koryo Style," in Koryŏ Sidae Pŏmjong Yangsik Ǔi Yŏn'gu, ed. Yi Ho-gwan (Seoul: Tanguk Taehakkyo, 1976), 189.

14 See Yŏm Yŏng-ha and Hanguk Chŏngsin Munhwa Yŏnguwŏn, Hanguk Chong Yŏngu (Seongnam: Hanguk Chŏngsin Munhwa Yŏnguwŏn, 1984), 8-49 for a complete study of this bell, and Hanŭl Kkotŭro Naerinŭn Kkaedarŭmŭi Sori (Kimchun: Chikchi sŏngbo Pangmulgwan, 2003), 8-11 for rubbings of its detailing. It is $167 \mathrm{~cm}$ tall (133.5 cm, minus the supporting loop) and $90.3 \mathrm{~cm}$ wide at its mouth (the rim is $4.7 \mathrm{~cm}$ thick), which is flat rather than scalloped. The design contains a more protruding set of nine "nipples"/lotuses on the squarish "lotus field" than the Sŏngdŏk Bell, but it is also decorated with celestial beings and lotus strike points.

15 Homer B. Hulbert, “The Great Bell,” The Korea Review, September 1902, 387; also quoted in in E. M. Cable, “Old Korean Bells,” Royal Asiatic Society Korea Branch 16, no. 1 (1925): 7. 


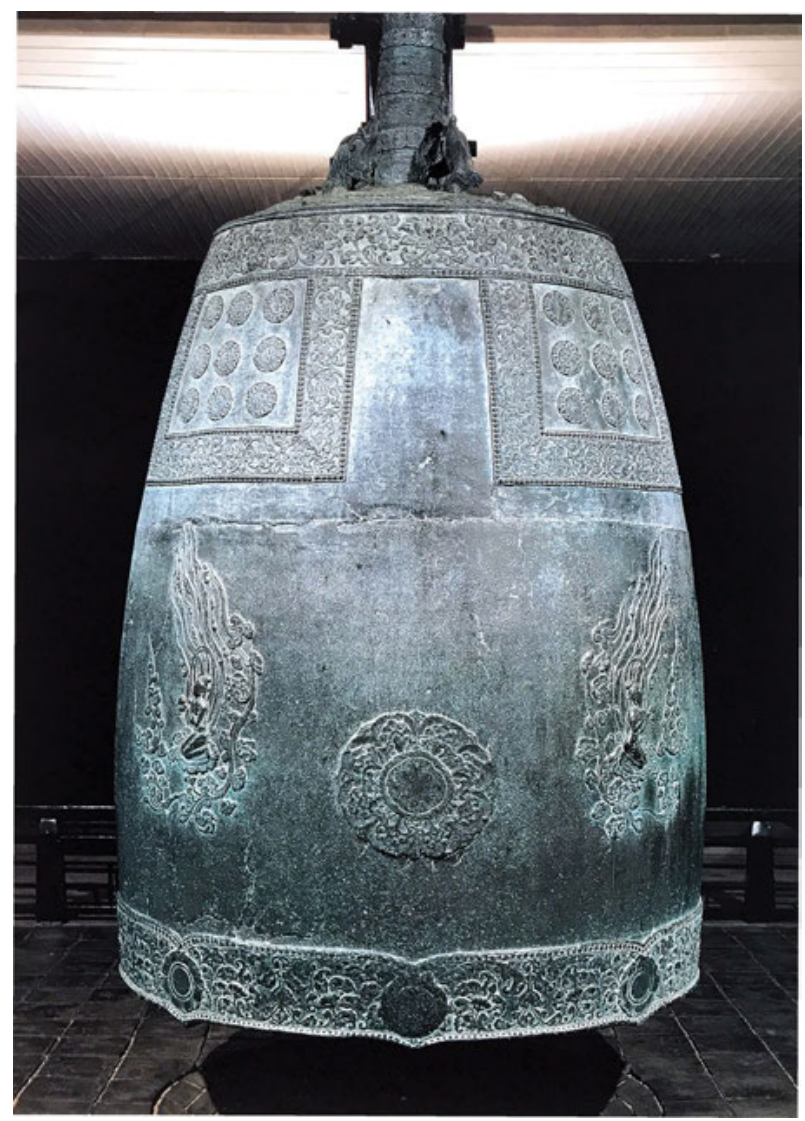

Figure 2: Photograph of the Sŏngdŏk Bell in Kungnip Kyŏngju Pangmulgwan, Sŏngdŏk Taewang Sinjong (Gyeongju: Kungnip Kyŏngju Pangmulgwan, 1999), vol. 2, 13.

One of the main differences between Chinese and Korean bells is the way that they were hung. Percival Price provides the following explanation, as well as offering a little of the Sŏngdŏk Bell's history:

The Chinese Buddhist bell was hung a storey above the ground, so that emanations would come down on to a deity, exemplified by a statue, who would know how to distribute it. The Korean bell was hung close to the ground, only about thirty centimetres above it in some cases, and the ground hollowed out underneath and kept clear of earth so as to facilitate the entry of its emanations into the earth. [. . .]

As it was believed that the ringing of the bell sent these spiritual emanations out to the ends of the world as well as down into the earth, so it was held that by making the bell 
larger, and thus increasing the power of its tone and the length of time it continued, the spiritual emanations would be stronger at distant points. The most effective bell would be the largest it would be possible to cast. Only a sovereign had the resources for this. In the second half of the eighth century the Silla king, Kyŏngdŏk [r.742-765], planned to offer such a bell to his deceased father, Sŏngdǒk [r.702-737], but he died before the bell was cast, and his son, king Hyegong [r.765-780], completed it in AD 771. ${ }^{16}$

The completion of the Sŏngdŏk Bell in 771 CE makes it roughly contemporaneous with the bSam yas Bell in Tibet, commissioned for Emperor Khri Srong lde brtsan (r.756-c.800) after he had begotten at least one son (see below). However, it is much larger than any of the Tibetan examples, $366.3 \mathrm{~cm}$ tall from its base to the top of the ingenious hollow tube (umt'ong, umgwan) rising above its dragonshaped supporting loop (yongnyu; $303 \mathrm{~cm}$ excluding this) and $222.7 \mathrm{~cm}$ wide at its mouth. The bell wall is on average $13 \mathrm{~cm}$ thick, but it gets thicker as it goes down to the mouth rim, which is $20.3 \mathrm{~cm}$ thick. ${ }^{17}$ It is estimated to weigh $72,000 \mathrm{~kg}$ and is one of only a handful of extremely large and heavy functioning bells in the world. ${ }^{18}$ The bell body is rather barrel-shaped, unribbed, and decorated at the top with three large square "fields" of nine lotuses (perhaps a throwback to the "nipples" or rowed protuberances on Zhou and Han bells). Below these, four heavenly apsaras or gandharvas make offerings on clouds interspersed with written epigraphy and two lotus-patterned striking points (tangjwa). ${ }^{19}$

The rim of the bell mouth (chonggu) is lightly scalloped to form a concave rather than a flat base, though creating small points in a manner quite unlike the Tibetan bells. The mouth's decorative band (hadae) follows the contours of the bell mouth's scallops (Figure 3). The mouth's decoration consists of tendrils reflecting the design of the shoulder edge (kyondae) above it, into which are placed six lotuses at each lowest point, or nadir, of the concave scallops. The circumference of the mouth is perhaps less strictly round than hexagonal when seen in cross section (no diagram of the exact measurement of the circumference seems to have been published), with the six points at each angle of the hexagon at regular intervals of $88.2 \mathrm{~cm}$ and protruding perhaps 5 or $6 \mathrm{~cm}$ downwards (again, the depth of the scallops has not apparently received

16 Price, Bells and Man, 36, col. i.

17 Yŏm and Hanguk Chŏngsin Munhwa Yŏnguwŏn, Hanguk Chong Yŏngu, 3 and 55, fig. 3. The hollow tube at the top means that the bell itself is open at both ends, yet it is unclear whether this addition improves the sound quality of its peal, simplifies the casting process, neither, or both.

18 Price, Bells and Man, 36, col. i.

19 Hanŭl Kkotŭro Naerinŭn Kkaedarŭmŭi Sori, 8-11 contains rubbings of some of its major details. All aspects of the bell are photographed in color in Kungnip Kyŏngju Pangmulgwan, Sŏngdǒk Taewang Sinjong, vol. 2 (Gyeongju: Kungnip Kyŏngju Pangmulgwan, 1999), 7-30. 


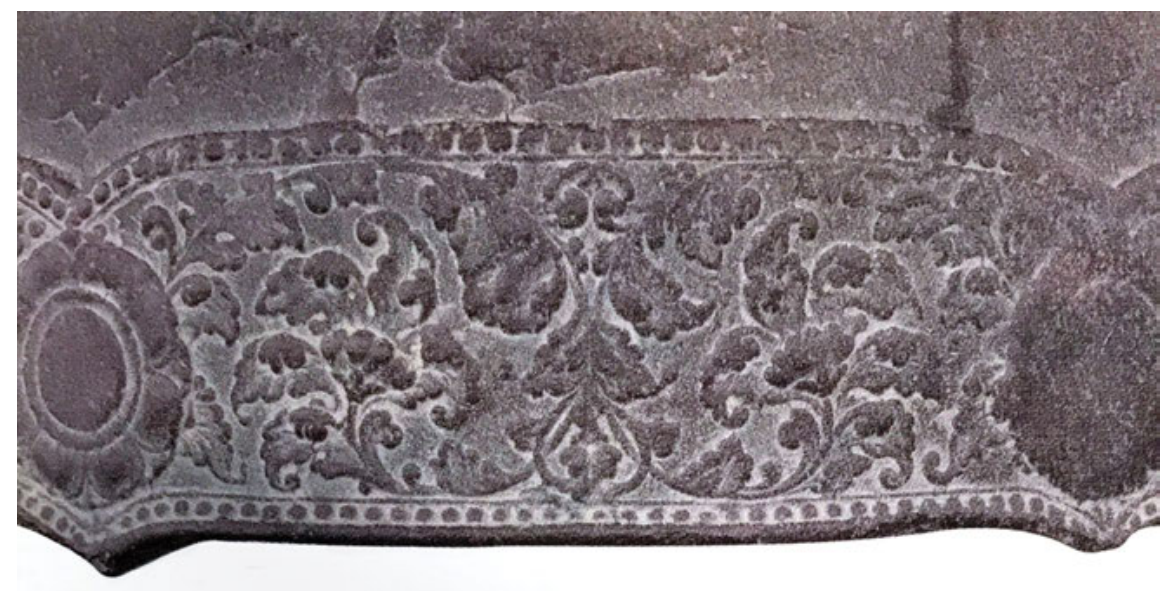

Figure 3: Photograph of the scalloping of the Sŏngdŏk Bell in Kungnip Munhwajae Yŏn'guso, and Ko Sŭng-gwan, Chuch ǒlchang: Chungyo Muhyŏng Munhwajae 112-ho, (Daejeon: P’ia, 2006), 20.

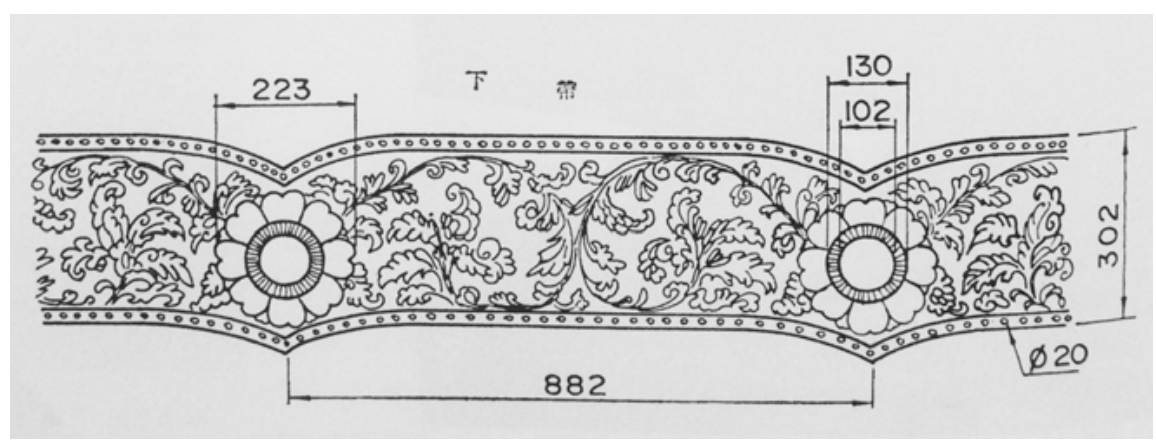

Figure 4: Drawing and measurements of the scalloping of the Sŏngdŏk Bell in Yŏm Yŏng-ha, and Hanguk Chŏngsin Munhwa Yŏnguwŏn, Hanguk Chong Yŏngu (Kyeonggi-do, Seongnam: Hanguk Chŏngsin Munhwa Yŏnguwŏn, 1984), 60, fig. 12.

detailed attention) (Figure 4). ${ }^{20}$ A photograph of the underside of the rim shows that the nadirs of the concave scallops are indeed points, and that they reach their nadir at the outer surface of the bell (Figure 5).

This division into six scallops does not seem to have a direct relation to the number of petals on a lotus, at least when compared to the more obvious lotus

20 Yŏm and Hanguk Chŏngsin Munhwa Yŏnguwŏn, Hanguk Chong Yŏngu, 60, fig. 12. 


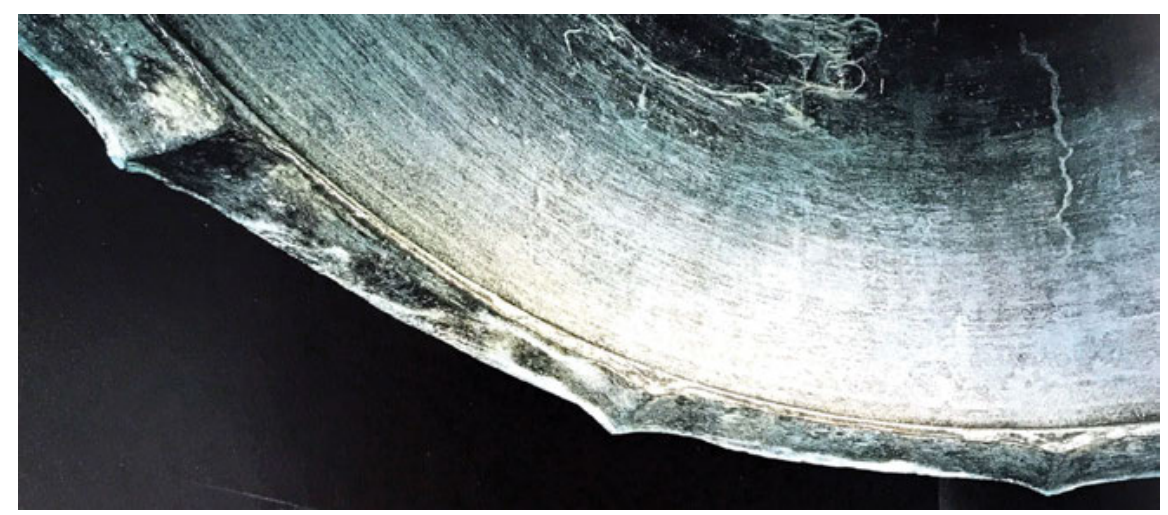

Figure 5: Photograph of the inside of the Sŏngdŏk Bell in Kungnip Kyŏngju Pangmulgwan, Sŏngdǒk Taewang Sinjong, vol. 2, 30.

depictions on the body of same bell. The lotus design on the hood (chonp'an) of the bell consists of thirteen inner and thirty-four outer petals. The nine lotuses arranged in three rows of three in the squarish "lotus field" (yon'gwak, yolloe) on the bell's shoulder (sangdae) each possess eight petals. The lotuses serving as striking points on the body of the bell possess eight inner and eight outer petals. The lotuses on the mouth's decorative band (hadae, showing tendrils reflecting the design of the shoulder edge [kyondae] above it) that follows the contours of the rim's scallops also possess eight petals. However, the hollow tube at the top appears to be designed with six-petalled double lotuses. ${ }^{21}$ There would be a fitting symmetry in a six-petalled lotus appearing at the top and bottom of the bell, but this line of inquiry requires further comparison with the tubes atop other Korean temple bells to corroborate or falsify it.

The scalloped bell is rare for Korean temple bells - thorough studies of contemporaneous and later Korean temple bells have found almost all of them to be flat mouthed..$^{22}$ Scalloped bases are found on only two later exemplars, one of which dates to 1346 , suggesting that the style did not completely die out after

21 See photographs in Kungnip Kyŏngju Pangmulgwan, Sŏngdŏk Taewang Sinjong, 2: 28-29. 22 See Yŏm and Hanguk Chŏngsin Munhwa Yŏnguwŏn, Hanguk Chong Yŏngu, 8-49 and 83ff. For a study devoted to the later maturation of temple bells during the Koryŏ period (918-1392 CE), see Yi Ho-gwan, Koryŏ Sidae Pŏmjong Yangsik Üi Yŏn'gu (Seoul: Tanguk Taehakkyo, 1976). A side-by-side comparison between three typical bells of different periods of Korean history is provided in Kungnip Munhwajae Yŏn'guso and Ko Sŭng-gwan, Chuch `ŏlchang: Chungyo Muhyŏng Munhwajae 112-ho, (Daejeon: P'ia, 2006), 17. 
the Silla period. ${ }^{23}$ Nonetheless, the Sŏngdŏk Bell still stands as a key example of the early art of scalloped bell casting and has thankfully been studied in great depth. ${ }^{24}$ This should act as a standard of best practice in the study of temple bells, to be emulated in the future with respect to Tibetan bells as well. At present, however, the quality of the data available on bells and bell-founding processes in other countries does not really compare to Korean-language scholarship, with the possible exception of Japanese literature on the subject.

\section{Japanese Bells}

Almost all extant Japanese temple bells are flat mouthed. However, the temple bell from Kasagi Temple (笠置寺鐘), Kyoto, cast in 1196, appears to be one of a small number of exceptions and a rare example of a very different form of scalloping (Figure 6). ${ }^{25}$ Its rim takes almost the opposite shape of that of the Sŏngdŏk Bell. Instead of six points sticking out of a flat mouth and creating a series of shallow concave lines from point to point, this bell has six grooves "cut" into the rim, creating a series of convex lines (more similar in this respect

23 The 1346 bell is tall and narrow, measuring $324 \mathrm{~cm}$ (263.9 cm without the supporting loop; $240.3 \mathrm{~cm}$ from the shoulder down) by $188 \mathrm{~cm}$ (described in Yŏm, Han'guk Ŭi Chong, 276-77; photographed in Hanŭl Kkotŭro Naerinŭn Kkaedarŭmŭi Sori, 212). Another, undated bell is smaller but maintains more barrel-like proportions, at $110 \mathrm{~cm}(92 \mathrm{~cm}$ without the supporting loop; $82 \mathrm{~cm}$ from the shoulder down) by $70 \mathrm{~cm}$ (described in Yŏng-ha Yŏm, Han'guk Ui Chong, 424-25; photographed in Hanŭl Kkotŭro Naerinŭn Kkaedarŭmŭi Sori, 216).

24 Especially in the two-volume work, Kungnip Kyŏngju Pangmulgwan, Sŏngdǒk Taewang Sinjong. The study also includes detailed sound recordings and sonographic analyses of its peal (Yŏm and Hanguk Chŏngsin Munhwa Yŏnguwŏn, Hanguk Chong Yŏngu, 69-80), drawings and measurements of all its parts both inside and out, and even creating replicas of the bell itself in order to imitate the process of its casting. This work (pp. 29; 32) describes how two replicas of this bell were cast in 1983, one measuring $255 \mathrm{~cm}$ by $150 \mathrm{~cm}$ and the other measuring $167 \mathrm{~cm}$ by $90 \mathrm{~cm}$. They are pictured in plates 40 and 43, respectively. A further replica was constructed in 1984, measuring $277.5 \mathrm{~cm}$ by $160 \mathrm{~cm}$ and weighing $7500 \mathrm{~kg}$ (p. 33; pictured in plate 46), just over a tenth of the weight of the original. The same work (pp. 64-69) deals with the ancient method of casting bells.

25 This image is taken from a special issue of Nihon no bijutsu on Buddhist bells (Nihon no bijutsu 日本の美術 [Art of Japan] 355: fig. 9). The description accompanying the figure states that the cuts into the mouth are $1 \mathrm{~cm}$ deep and “form a six-petalled shape” (六葉形に作る). Furthermore, it claims that this follows a Chinese model, and that a further example of a sixpetalled temple bell is housed at the Todaiji Great Exhibition Centre (東大寺大勧進所). See also Hashizume Kinkichi (橋爪金吉) and Asano Kiichi (浅野喜市), Bonshō Junrei 梵鐘巡礼 (Tokyo: Bijinesukyōikushuppansha ビ ジネス敎育出版社, 1976), 185 and plate 138. 


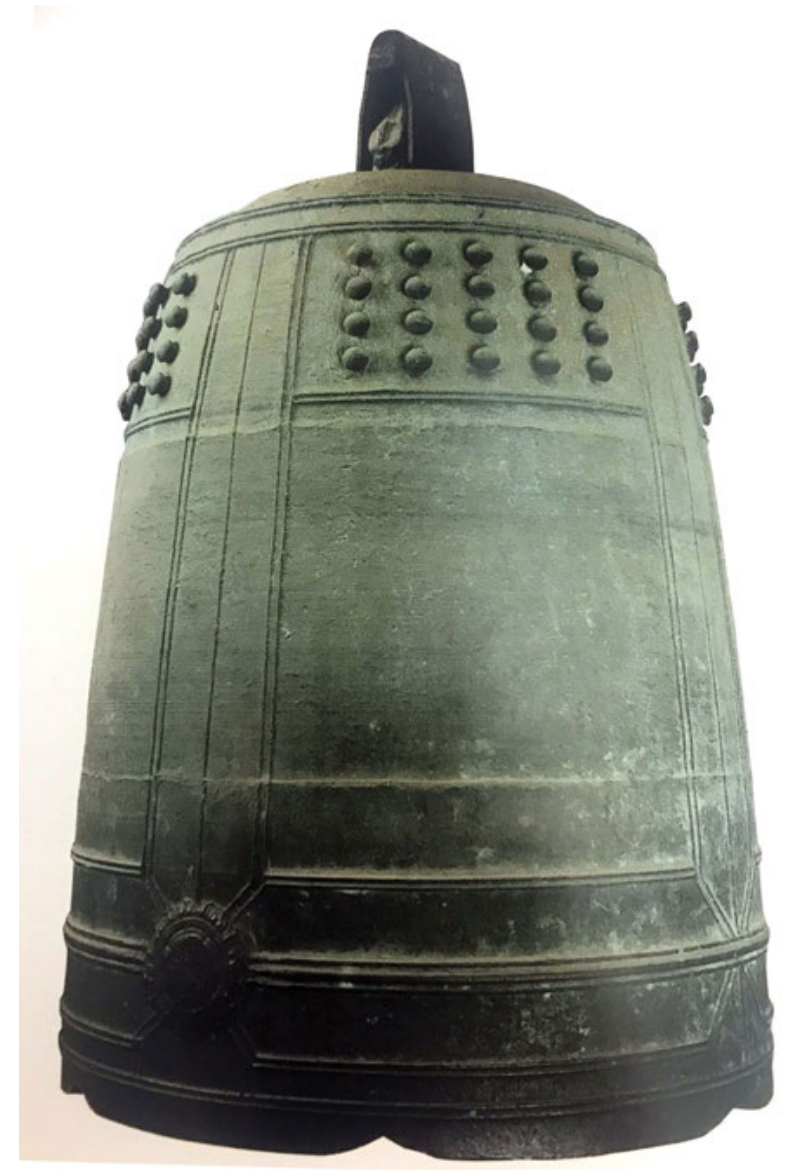

Figure 6: Photograph of the Kasagi Temple Bell in Nihon no bijutsu日本の美術 [Art of Japan] 355 (1995): fig. 9.

to the scalloping of Korean tantric handbells). ${ }^{26}$ In all other respects, it appears to be a classic Japanese-style temple bell, with its striking points and "nipples" or rowed protuberances emulating earlier East Asian (predominantly Chinese) models like the Sŏngdŏk Bell does in a different way.

A more standard scalloped bell, probably from the early part of the Muromachi period (ca. 1336-1573), is found in the Jissō-ji temple (実相寺) in Nishio, Aichi

26 On the design of Korean tantric handbells, see for example Ch’oe Ŭng-ch’ŏn and Kim Yŏnsu, Kŭmsok Kongye (Seoul: Sol, 2004), 180-90. 
prefecture (Figure 7) ${ }^{27}$ The rim of this bell is molded into eight scallops, conforming to the number of petals in classical lotuses or following a later stylistic trait of bells, most likely cast in Japan in imitation of Chinese design. ${ }^{28}$ However, it lacks a striking point or lotuses in the rest of the design and instead the body is split into three rows of four panels, separated by triple bands and ornamented with twelve vertically elongated hexagons that are situated either in the middle of the panels (middle row) or at the panel changeovers (top and bottom rows). ${ }^{29}$

\section{The Jingyun Bell, China}

Closer in space and time to imperial Tibet, the scalloped bronze Jingyun Bell (景雲钟), cast in 711, was hung in the bell tower of a Daoist monastery in Chang'an (modern-day Xi'an), but has resided in the Beilin "Forest of Stone Steles" Museum since 1953 (Figure 8). ${ }^{30}$ The bell measures $247 \mathrm{~cm}$ in height,

27 The bell measures $138.7 \mathrm{~cm}$ high ( $112.3 \mathrm{~cm}$ without the loop; $106.5 \mathrm{~cm}$ from the shoulder), $80.4 \mathrm{~cm}$ wide at its rim (which is $9.2 \mathrm{~cm}$ thick). See Tsuboi Ryōhei (坪井良平), Bonshō No Kenkyū 梵鐘の研究 [A study of the bell] (Tokyo: Bijinesu Kyōiku Shuppansha ビジネス教育出 版社, 1991), 108-11.

28 Tsuboi, Bonshō No Kenkyū, 108-109. On page 110, Tsuboi compares this exemplar with the very similar diagram of the Chinese design that likely inspired this fine imitation.

29 Two other such plain, large, eight-scalloped Chinese temple bells dating from the early fifteenth century are associated with Beijing's famous bell tower and the Yongle emperor (1360-1424); an iron bell of $420 \times 240 \mathrm{~cm}$ ( 25 tons) that was replaced by a larger bronze bell of $700 \times 340 \mathrm{~cm}$ ( 46.5 tons) that produced a better peal (see Ben Nijhoff's entry on the Beijing bell tower: "Bell Tower Platform \& Yongle Era Bronze Bell," The China Report, www.drben.net, last modified June 18, 2017, http://www.drben.net/ChinaReport/Beijing/Landmarks-Hotspots /DongCheng/Zhong_Lou-Bell_Tower/Bell_Tower5-Bell_and_Platform1-South.html). Both lack striking points and are patterned with two rows of oblongs separated by horizontal bands. These stand in contrast to the contemporaneous Yongle Grand Bell housed in the Great Bell Temple (Da Zhong Si) just outside Beijing, which weighs 50 metric tons and measures about $700 \mathrm{~cm}$ high (500 cm without the suspension loop) and roughly $450 \mathrm{~cm}$ in diameter (Price, Bells and Man, 13, col. ii). That bell is also scalloped but is covered top to bottom with epigraphy in Chinese script. The first two exemplars therefore resemble the Japanese example more closely but lack the elongated hexagonal design.

30 See Michael Yang's entry on the Xi'an bell tower ("The Bell Tower," Xi'an Travel Guide, China Highlights, last modified October 4, 2017, http://www.chinahighlights.com/xian/attrac tion/bell-tower.htm), where he also states: “The Xi' an Cultural Relics Bureau made a replica of [the] Jingyun Bell and hung it in the north-west corner of the Bell Tower on January 30th, 1997 , which is 2.45 meters ( 8 feet) tall and 6.5 tons (14,330 pounds) in weight, with an inscription carved on it." One can ring the replica for a fee, but the original apparently was deadened 


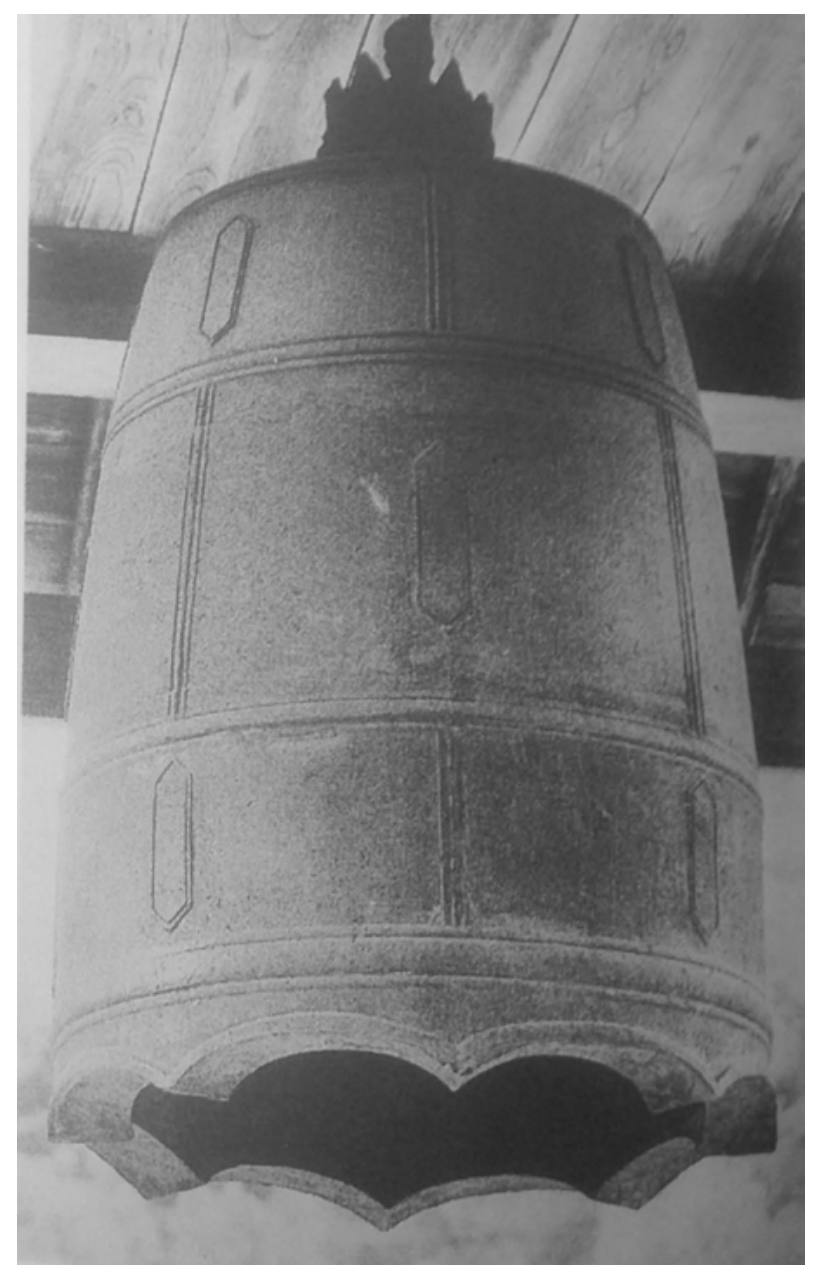

Figure 7: Photograph of the Jissō-ji Bell in Tsuboi Ryōhei (坪井良平), Bonshō No Kenkyū 梵鐘の 研究 [A Study of the Bell] (Tokyo: Bijinesu Kyōiku Shuppansha ビ ジネ ス教育出版社, 1991), 109.

$165 \mathrm{~cm}$ in width across the bottom, and weighs 6,500 kg. ${ }^{31}$ Price writes, "The form is Korean and suggests Korean workmanship. Korean bellfounders are

during a move of the bell tower in 1582, during the Ming Dynasty (Marilyn Shea, "Forest of Steles," Xi'an in Pictures, China, last modified March 2010, http://hua.umf.maine.edu/China/ Xian/pages/205_Xian_Forest_of_Steles.html).

31 Dimensions given in "The Bell Tower," Top China Travel, accessed November 22, 2019, http://www.topchinatravel.com/china-attractions/the-bell-tower.htm. 


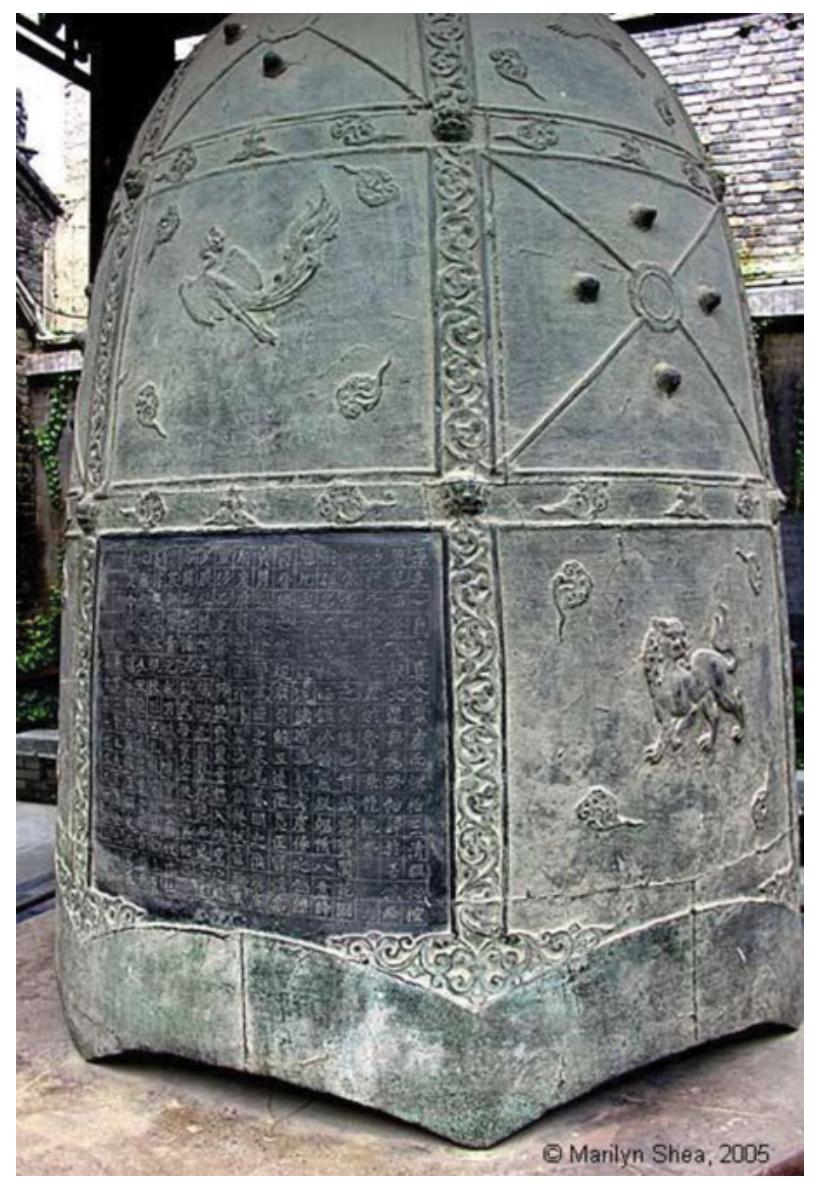

Figure 8: The Jingyun Bell, Marilyn Shea copyright 2005.

said to have cast the first very large bells in China, having cast large bells in Korea earlier." 32 The bell was commissioned by the Tang dynasty (618-907) emperor Ruizong (662-716) and was cast in the second year of the Jingyun era. ${ }^{33}$ This bell evidently remains popular to this day, though undoubtedly some confuse the replica for the original. ${ }^{34}$

32 Price, Bells and Man, 11, col. ii.

33 Shea, "Forest of Steles."

34 Jumei Yang, in a blog on the Beilin Museum (though I suppose with reference to the replica; see above on the deadened original), says, "its ring is so beautiful that it was recorded by CCTV (A mainstream Chinese television station) and played on New Years' eve to celebrate the coming 
Like the Sŏngdŏk Bell, the Jingyun Bell possesses a hexagonal rim because of its six scallops. It is not possible to see the underside of the original bell, but images of the replica now hanging in the Xi'an bell tower (Figure 9) ${ }^{35}$ suggest that, unlike the Sŏngdŏk Bell, the concave arches of the Jingyun Bell's scallops end in edges rather than points, though the nadirs are still on the outer face of the bell. Of course, the replica makers may not have followed every design trait of the original.

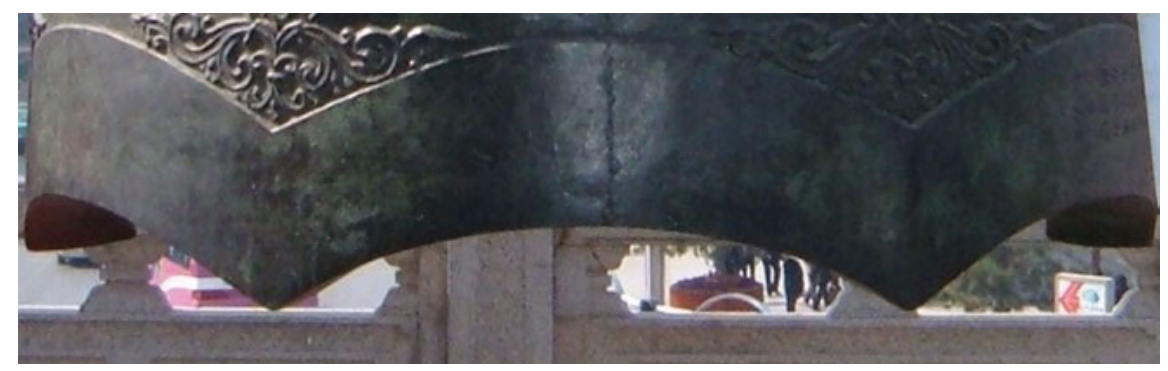

Figure 9: Scalloping on the Jingyun Bell, Wikimedia Commons copyright 2008.

The sixfold scallops are mirrored in three rows of six panels, separated by vertical and horizontal bands containing tendrils and clouds respectively. Clouds, which are incidentally a feature of the Sŏngdŏk Bell's design too, also feature within the nine illustrated panels, surrounding symbolic animals such as the dragon, phoenix, lion, and ox. These illustrated panels are interspersed with a design comprising two crossed diagonal lines intersecting at an eight-petalled lotus striking point. From the middle of each of the triangles created by the crossed lines blossoms a single lotus striking point, and around these are four "nipple" protuberances, perhaps, like the Sŏngdŏk Bell, harking back to those of earlier musical bells. On the bottom row, this interspersal is broken by the inclusion of one panel bearing epigraphy in 293 characters. This inscription describes the benefits and mysteries of Daoism, while also in part praising the bell. ${ }^{36}$

of a new year. Moreover, the Bell was printed on the Chinese stamp in 2000 and was at the time thought of as 'the best bell in the world' by local people." Source accessed January 14, 2017, http://www.guidewetravel.com/the-stele-forest-xian-beilin-museum/ (site discontinued).

35 “Jingyun Bell,” 2007, Xi’an, China, https://commons.wikimedia.org/wiki/File:Jingyun_ Bell.JPG.

36 See Shea, "Forest of Steles." 
Price states that the scallop-rimmed bell style continued to be popular in northern China, whereas flat-mouthed bells were preferred in the south. ${ }^{37}$ Another six-scalloped temple bell, probably founded in the tenth century, was given as the second type of Chinese temple bell (bell 3) in the diagram in Figure 1, above. ${ }^{38}$ It was cast in Song-dynasty (960-1279) China, but is now apparently held in Incheon, South Korea. It is $258 \mathrm{~cm}$ high $(191 \mathrm{~cm}$ without the loop; $157 \mathrm{~cm}$ from the shoulder), $158 \mathrm{~cm}$ wide at the mouth. The rim is $14 \mathrm{~cm}$ thick, unlike the rest of the bell wall, which is on average $5 \mathrm{~cm}$ thick. It possesses two rows of three oblong panels, and a lower decorative band ornamentation that resembles the Jingyun Bell's lower decorative band in terms of its pattern. A slightly later, but similar six-scalloped iron bell, measuring $164 \mathrm{~cm} \mathrm{x}$ $100 \mathrm{~cm}$ and weighing 1 ton, is now also kept in Incheon, at the Jeondeungsa Temple (전등사철종) on Ganghwa island (Figure 10). It was cast in 1097 in Northern Song-dynasty China and shares the simpler design of the scalloped example in Figure 1, above. However, it lacks that bell's lower decoration, and its scallops end in longer points. ${ }^{39}$ The continued popularity of the scallop-rimmed temple bell up to the Manchu period is evidenced in the famous Nanking Bell, from the Manchu Temple in Nanjing.

Reviewing the extant early East and Southeast Asian temple bells shows their variety of size, form, and style across this part of Buddhist Asia. This is due in part to the fruitful aesthetic dialogue that took place especially between Chinese, Korean, and Japanese artisans and the borrowing of stylistic elements across porous borders during this period. Furthermore, we have seen that even within first-millennium China, which appears to be at the heart of this nexus, there is a lack of homogeneity in temple-bell design, and so no single "Chinese pattern" that Tibetans of this era could easily emulate.

\section{Tibetan Bells}

No doubt the eighth-century Tibetans who came to the Tang capital of Chang'an (now Xi'an) heard or saw Buddhist or Daoist temple bells and perhaps the scalloped Jingyun Bell itself. One could even imagine such a bell being sounded in

37 Price, Bells and Man, 12.

38 The following description is based on Kungnip Kyŏngju Pangmulgwan, Sŏngdŏk Taewang Sinjong, vol. 1, 211 and “강화 전등사 철종,” Wikipedia, last modified November 17, 2019, https://ko.wikipedia.org/wiki/강화_전등사_철종.

39 Ch'oe and Kim, Kŭmsok Kongye, 90-91. 


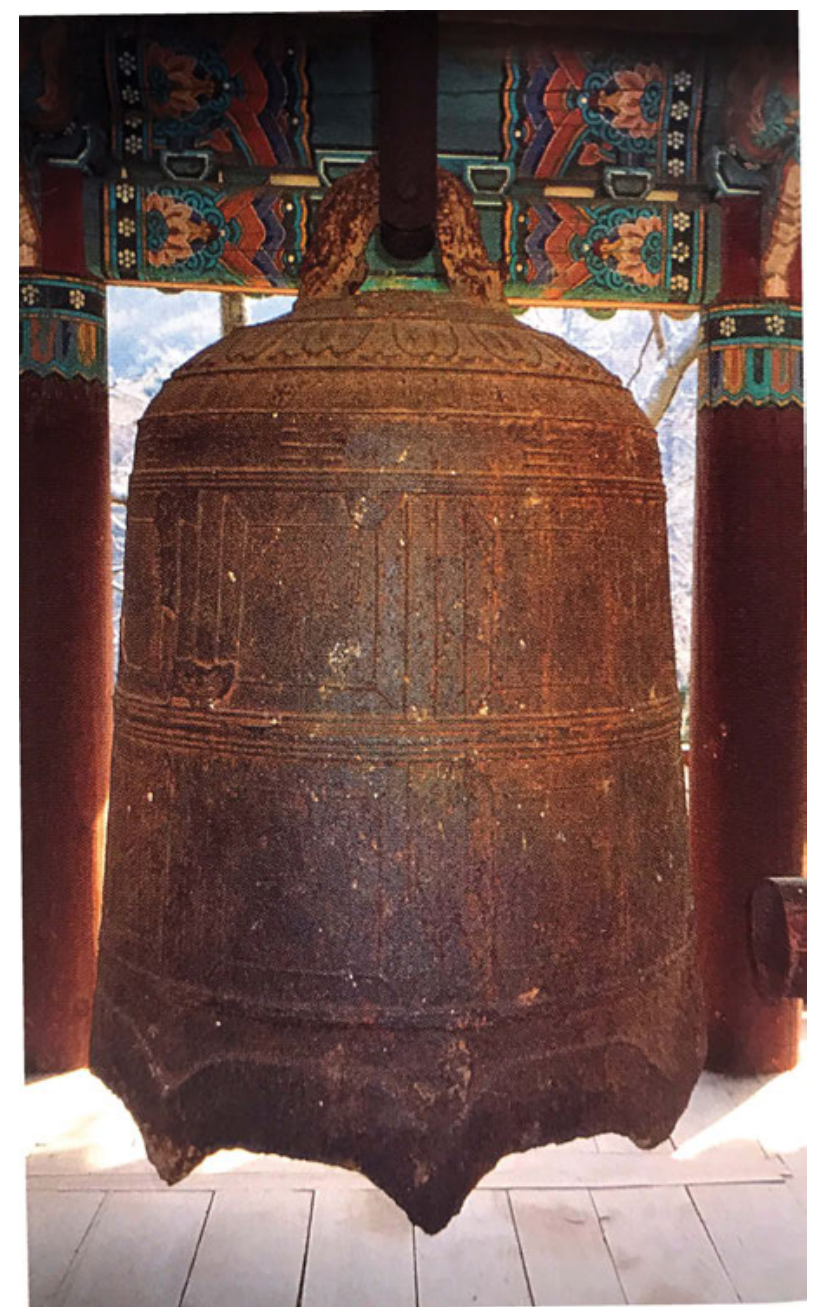

Figure 10: Photograph in Ch'oe and Kim, Kŭmsok Kongye, 90.

warning as the Tibetan military attacked Chang'an to sack it in $763 .{ }^{40}$ In the context of the westward spread of temple bells, Walther Heissig states that inscribed Chinese Buddhist bells were found "at sites of the seventh-century Kirghiz

40 On this brief conquest, see Christopher I. Beckwith, The Tibetan Empire in Central Asia: A History of the Struggle for Great Power among Tibetans, Turks, Arabs, and Chinese During the Early Middle Ages (Princeton: Princeton University Press, 1987), 146. 
kingdom in the region bordering the Yenisei river." 41 However, I have been unable to find corroboration of this assertion elsewhere, including in the passage that he cites from C. B. Kiselev. ${ }^{42}$ Notably, the Tibetan bronze exemplars appear to imitate the simpler Chinese designs that were described at the end of the last section, rather than the complex imagery and extensive epigraphy of Tang China's Jingyun Bell or Silla Korea's Sŏngdŏk Bell (though see below on the iron bell recently discovered in dPa' ris, 5चर'خेत').

Giuseppe Tucci was one of the first Western scholars to take an interest in Tibetan temple bells seeming to date from the imperial period (ca. 600-850). In his Tombs of the Tibetan Kings, Tucci identifies three bells from central Tibet -

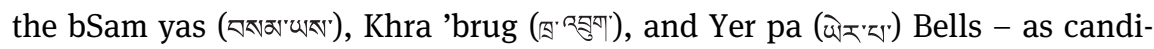
dates for inclusion within such a group, because they all hung at sites important to the imperial propagation of Buddhism as a state religion and, he believed, included the name of a Tibetan emperor cast into the bell as part of its epigraphy. ${ }^{43}$ Tucci also includes in this work a photograph of the bSam yas Bell in situ at the entrance to the famous bSam yas Monastery, and a transcription and translation of its inscription. ${ }^{44}$ Hugh Richardson has since revisited and improved the readings and translations of the bSam yas, Khra 'brug, and Yer pa Bell inscriptions. ${ }^{45}$ Further afield, Michael Aris has brought attention to

41 Walther Heissig (Geoffrey Samuel transl.), The Religions of Mongolia (Berkeley: University of California Press, 1980), 4. In the original German, Heissig refers to "Buddhistische Templeglocken mit chinesischen Aufschriften, die auf Fundstellen des Kirgisenreichs des 7. Jahrhunderts im Jenisseigrenzgebiet zutage gefördert wurden, weisen darauf hin, daß buddhistische Einflüsse in diesen Gebietenweiterhin andauerten" (Giuseppe Tucci and Walther Heissig, Die Religionen Tibets und der Mongolei (Stuttgart: Kohlhammer, 1970), 302).

42 Footnote 16 on the same page of the German edition refers to page 615 of the 1951 work of the C.B. Kiselev (Tucci and Heissig, Die Religionen Tibets und der Mongolei, 320, n. 16 (translated in an endnote in Heissig, The Religions of Mongolia, 114, n. 16). However, the corresponding page of Kiselev's work (and pages around it) do not appear to mention bells at all, but rather a Chinese inscription on a bronze altar monument that Kiselev dates to the sixth century (and its appearance near the Yenisei to the ninth century). Furthermore, Kiselev interprets the monument as booty, rather than as showing the influence of Buddhism in the area. See C.B. Киселев [Kiselev], Древняя история Южной Сибири [Drevniaia Istoriia Iuzhnoй Sibiri] (Moscow: Изд-во Академии наук CCCP [Izd-vo Akademii nauk USSR], 1951), 614-16.

43 Tucci, The Tombs of the Tibetan Kings, 69-71. Tucci believed that the Yer pa Bell had included the name of a Tibetan emperor in the area of the bell inscription that had been lost when the bell cracked (Tucci, The Tombs of the Tibetan Kings, 71). Hugh Edward Richardson has since rightly disputed this (Richardson, “A Ninth Century Inscription”: 166).

44 Tucci, The Tombs of the Tibetan Kings, fig. 5; 108, Appendix VIII; 69.

45 See Richardson, “A Ninth Century Inscription”: 166-71; Hugh Edward Richardson, A Corpus of Early Tibetan Inscriptions (London: Royal Asiatic Society, 1985), 32-35, 82-83 and 144-47. This has been followed by further discussion, transliteration and translation of all three bell 


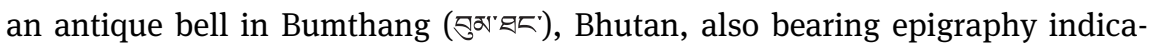
tive of an imperial-period date. ${ }^{46}$ Finally, a bell made of iron (rather than bronze) has recently surfaced in $\mathrm{dPa}$ ' ris near Xining in China, purportedly founded during the Tibetan imperial period and showing more prominent ornamentation (Figure 11). ${ }^{47}$ However, here I shall deal with the bronze bells alone and focus less on the inscriptions (except where those elements have a bearing on the form of the bells) than on their design and the extent and shape of their scalloping. Though there is some variation among the exemplars, it will be seen that they tend to be rounded or pointedly concave at their bases, forming scallops in higher relief than the Sŏngdŏk Bell or Japanese examples above (Figures 2 to 7). In this way (as in their simpler design), they resemble the Song Chinese bells discussed at the end of the last section, as well as the Jingyun Bell to an extent (Figures 8 to 10).

inscriptions in Li and Coblin, A Study of the Old Tibetan Inscriptions, 332-39, 340-46 and 347-52. More recent transliterations of the bell epigraphs are found in Iwao Kazushi (岩尾一史) et al., Old Tibetan Inscriptions: Old Tibetan Documents Online Monograph Series II (Tokyo: Research Institute for Languages and Cultures of Asia and Africa, Tokyo University of Foreign Studies, 2009), 70, 71 and 72.

46 Michael Aris, Bhutan: The Early History of a Himalayan Kingdom (Warminster: Aris \& Phillips, 1979), 33-36 and plate 6.

47 See lHa mchog skyabs (兰却加), “Btsan po khri lde btsug brtsan skabs kyi jag rog dga' ldan byin chen gtsug lag khang gi dril bu'i kha byang gi yi ger dpyad pa” [Remarks on the text of a bell of the Jag rog dga' ldan byin chen sanctuary from the time of Emperor Khri lDe btsug brtsan]. Bod ljongs zhib 'jug/西藏研究/Tibetan Studies 1 (2001): 1-9. This relatively small and squat $54 \mathrm{~cm} \times 52 \mathrm{~cm}$ iron bell bears a Tibetan inscription prominently featuring Emperor Khri lDe gtsug brtsan (r. 712-ca. 754) and stating that it was cast by a monk (dge slong). See also Michael Willis's blog: "Bell at dPa' ris," Indological Notes and Queries, last modified October 16, 2001, http://dogankoy.blogspot.com/2011/10/bell-at-dpa-ris.html. Mention of the emperor is not proof that the bell dates to his reign, but if it does date that early, then it would be the earliest extant example of both Tibetan temple bells and also imperial Tibetan epigraphy. The image in figure 11 is taken from journalist bDe 1Ha mo's Tibetan-language article online concerning the discovery: last modified May 4, 2011, http://zw.tibetculture.org.cn/news_1/tplt/201105/ t20110504_1022719.htm. The six scallops are in high relief and undulating in quality, ornamented with what resemble the faces of the mythical kirtimukha beast (my thanks to Amy Heller for pointing out the similarity). The body of the bell lacks a striking point, like other Tibetan temple bells (with the possible exception of the Bumthang Bell, below), but also lacks the ribbing present in Tibetan examples, and the epigraphy is not confined to panels or the top of the bell, but covers the whole (admittedly smaller) surface area of the body. Lastly, the dPa' ris Bell's cloud patterns resemble those on the Jingyun Bell (Figure 8), although other, more proximate sources for this design element exist in central Tibet. 


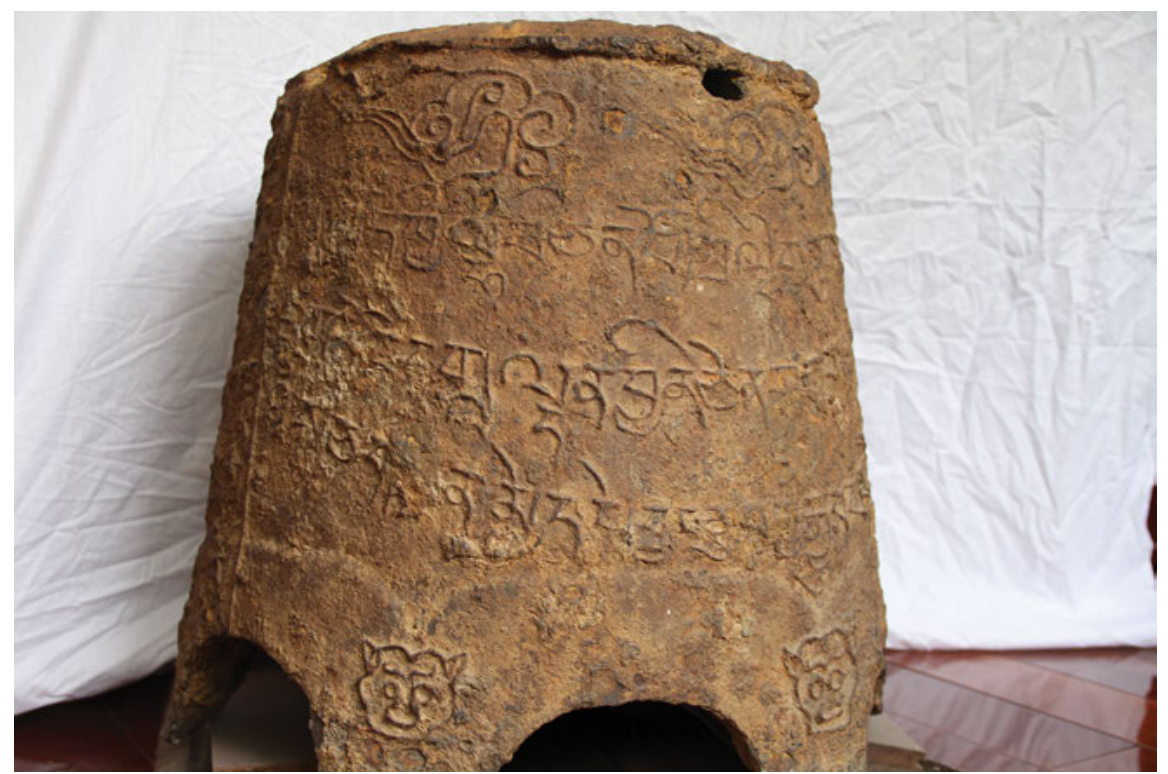

Figure 11: The dPa' ris Bell, China Association for Preservation and Development of Tibetan Culture (CAPDTC) copyright 2011.

\section{The bSam yas Bell}

The Tibetan empire reached its greatest extent during the reign of the Tibetan emperor (btsan po) who is the focus of the bSam yas Bell inscription, Khri Srong lde brtsan (r. 756-ca. 800). In the northwest, the empire threatened the Caliphate of Harun Al-Rashid on the banks of the Oxus; in the east, as mentioned above, Tibetan armies even briefly sacked the Chinese capital Chang'an in $763 \mathrm{CE} .{ }^{48}$ This Tibetan emperor also presided over the growing institutionalization of Buddhism in his realm, epitomized by his patronage of bSam yas Monastery. From Tucci's image, as well as other photographs taken since, we can see the brightly colored beams and ceiling of the entrance hall leading to the main temple, into which spectacular location the bell is placed like a hanging jewel to catch the eye of visitors entering the monastery's central place of devotion.

These photographs, taken from below the bell looking up, also clearly show the bSam yas Bell's six scallops and the similarity of their design to the

48 See Beckwith, The Tibetan Empire, 143-57. 


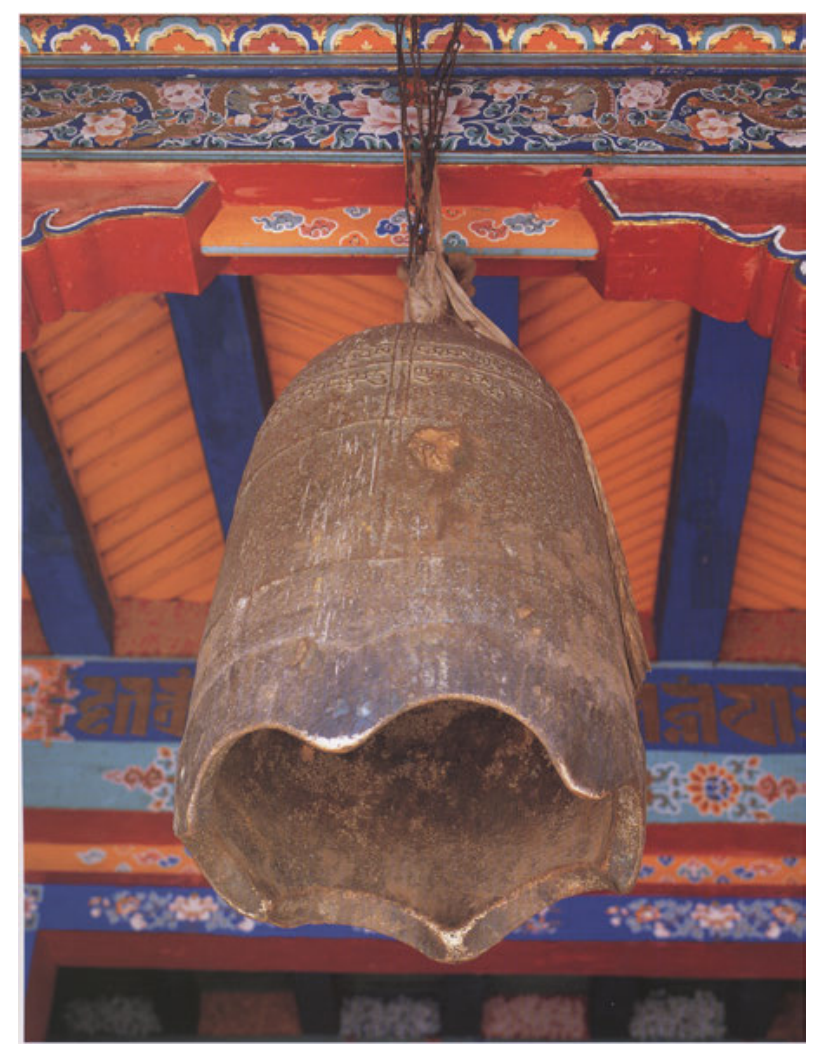

Figure 12: The bSam yas Bell in 'Jam dbyangs (甲央), and Wang Mingxing (王明星), Baozang 寶藏 [Precious deposits: Historical relics of Tibet, China], vol. 1 (Beijing: Chaohua chubanshe 朝 華出版社 [Morning Glory Publishers], 2000), 164, plate 97.

larger Jingyun Bell. ${ }^{49}$ Like the Sŏngdŏk Bell, however, the concave arches reach points at their nadirs, which lie on the outer face of the bell. These points are perhaps most rounded on the bSam yas Bell, which lacks the tendril design that decorates the Jingyun Bell above the mouth's decorative band and the Sŏngdŏk Bell's band itself. Instead, the bSam yas Bell is more plainly decorated with vertical and horizontal ribs (the former positioned in line with the nadir of each scallop). At the top, two lines of epigraphy are cast into the bell, split by the ribs into twelve segments (six are visible in Figure 13). A few of the syllables

49 See also Takeuchi Tsuguhito's (武内 紹人) photograph, showing another side of the bell, in Iwao et al., Old Tibetan Inscriptions, xv, plate 9. 


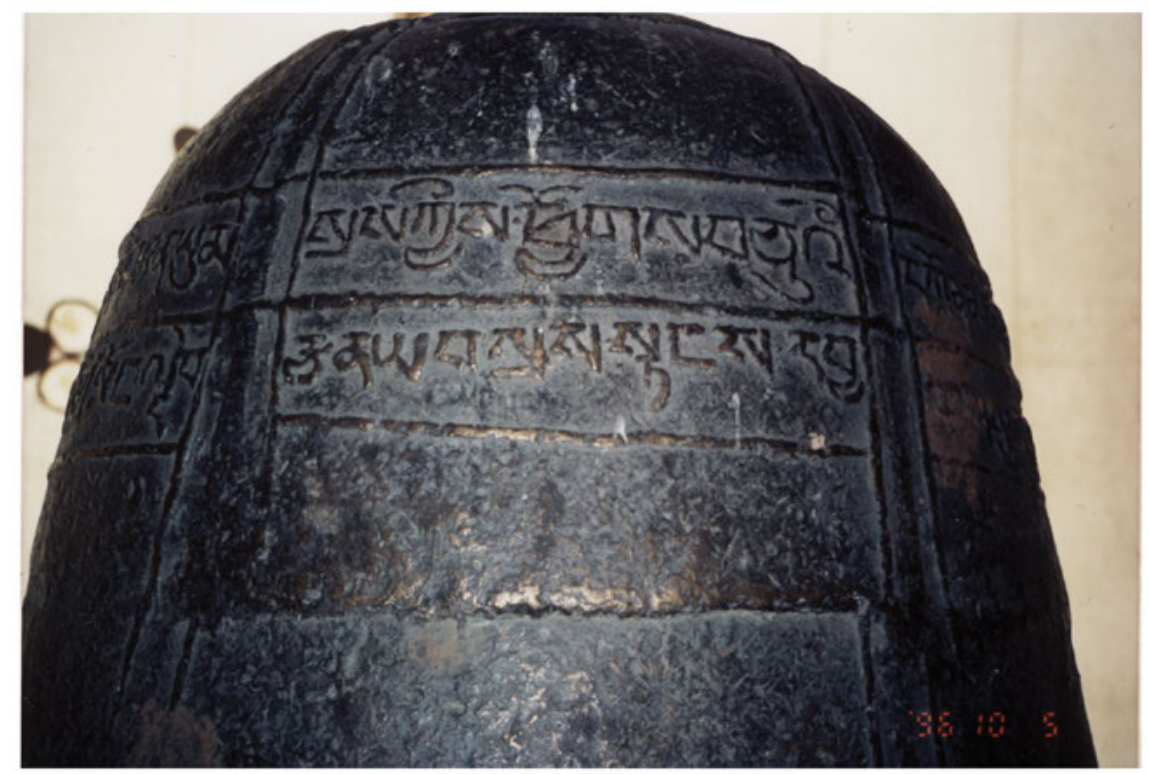

Figure 13: Takeuchi Tsuguhito's (武内 紹人) photograph of part of the bSam yas Bell Inscription in Iwao Kazushi (岩尾一史) et al., Old Tibetan Inscriptions: Old Tibetan Documents Online Monograph Series II (Tokyo: Research Institute for Languages and Cultures of Asia and Africa, Tokyo University of Foreign Studies, 2009), xvi, plate 10.

of the inscription, bsod, brtsan, and dbyal, even cross over the ribs (the syllable " $b-$-rtsan" can be seen at the far left of Figure 13), perhaps suggesting that the placement of these ribs took precedence over the epigraphy among the design priorities of the bell founder. As can also be seen in Figure 13, the horizontal ribs are less than completely horizontal, and the vertical ribs are broken up by the joins of the slabs used to mold the inscription into the bell.

The inscription, whose raised letters display paleographic and orthographic features of the ancient Old Tibetan writing style, dedicates the bell (cong < zhong 鐘) to Emperor Khri Srong lde brtsan, on behalf of his queen, Jo mo rGyal mo brtsan, and their son (sras), who both commissioned the bell's construction. Because of these references, Richardson dates the bSam yas Bell to between 780 and $790 .^{50}$

50 Richardson, A Corpus of Early Tibetan Inscriptions, 33. 
A sense of the bell's proportions is more easily discerned in a photograph taken when it was lying in a courtyard or open area (Figure 14). Unfortunately, no scholar appears to have published measurements of these bells. Although Tucci refers to the bSam yas Bell as "huge," we have no reason to think it was much over $100 \mathrm{~cm}$ tall. ${ }^{51}$ However, the bell is still in the entrance to bSam yas Monastery (where it was photographed in Figure 12), and so it may still be possible to discover its exact dimensions.

\section{The Khra 'brug Bell}

As Michael Walter points out, bSam yas is "not the oldest, but the most famous early Tibetan monastery." 52 The Khra 'brug Monastery is considered another of the oldest Tibetan monasteries or temple complexes in existence. ${ }^{53}$ It lies in the Yar klung valley, home of the imperial dynasty. ${ }^{54}$ From the roof of its outer gateway (leading onto a courtyard in front of the main temple) hung a large, cracked bell whose whereabouts are unknown today, ${ }^{55}$ but which from the images available resembles the bSam yas Bell quite closely (Figures 15 and 16).

The Khra 'brug Bell also lacks measurements. However, roughly comparing its size with the people in Figure 16 suggests that it measured about $100 \mathrm{~cm}$ in

51 Tucci, The Tombs of the Tibetan Kings, 69. Richardson, A Corpus of Early Tibetan Inscriptions, 82, states that it is smaller than the Khra 'brug Bell, which appears to measure roughly $100 \mathrm{~cm} \times 60+\mathrm{cm}$ (see below), giving some indication of the size of bSam yas Bell and placing Tucci's "huge” in context.

52 Michael L. Walter, Buddhism and Empire: The Political and Religious Culture of Early Tibet (Leiden: Brill, 2009), 187.

53 See especially Per K. Sørensen, Guntrum Hazod, and Tsering Gyalbo, Thundering Falcon: An Inquiry into the History and Cult of Khra-'Brug, Tibet's First Buddhist Temple (Vienna: Österreichischen Akademie der Wissenschaften, 2005). The mention of a "bKra shis lha yul of Khra 'brug” in the explanatory proclamation ( $b K a$ ' mchid) of Khri Srong lde brtsan (Richardson, A Corpus of Early Tibetan Inscriptions, 26) suggests that it was in existence before the reign of Khri lDe srong brtsan (mentioned in the Khra 'brug Bell inscription). Therefore, while bSam yas Monastery contains a bell dedicated to the emperor who built it as a monastery or complex of temples, this may not be the case with the Khra 'brug Monastery (unless he turned a fledgling religious community into a full-blown monastery with ordained residents), in contrast to the opinion of Tucci (The Tombs of the Tibetan Kings, 71).

54 The coordinates $29.1^{\circ} \mathrm{N}$ and $91.7^{\circ} \mathrm{E}$ are given in Iwao et al., Old Tibetan Inscriptions, 71.

55 The Khra 'brug Bell's condition is still "lost" according to Iwao et al., Old Tibetan Inscriptions, 71; Li and Coblin (A Study of the Old Tibetan Inscriptions, 340) report that it was lost sometime between 1965 and 1987. 


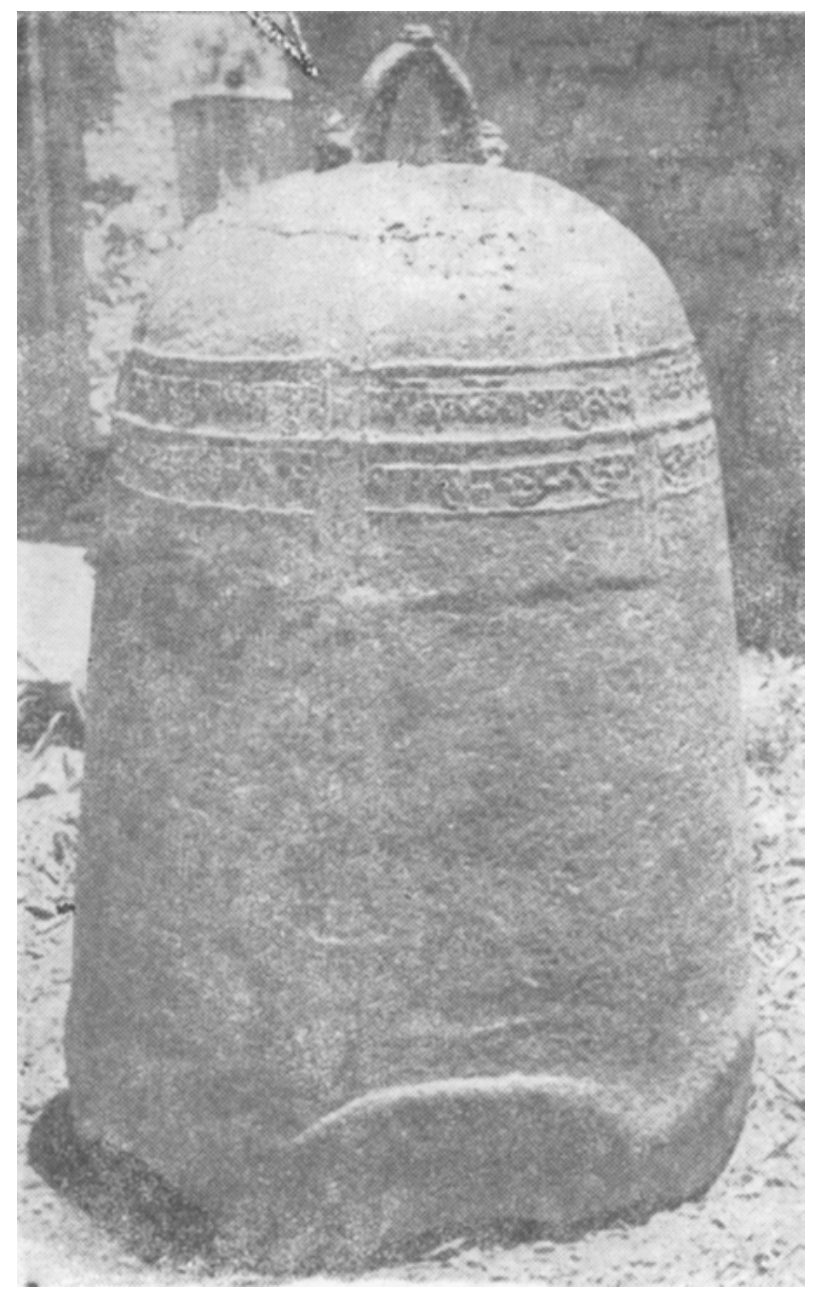

Figure 14: A photograph of the bSam yas Bell in An Xu (安旭), “Xizang Sangyuan si zhudian bihua lüekao 西藏桑鴶寺主殿壁畫略考 [“Notes on the Wall Paintings in the Main Hall of Sang Yuan Temple Xizang (Tibet)”], Wenwu 文物 [Cultural Relics] 1982(8): 6, plate 10.

height and over $60 \mathrm{~cm}$ in diameter. Until it was lost, the bell was evidently hung up high, like the bSam yas Bell, and most scholars report that a ladder was needed in order to read both their inscriptions. Here, the Khra 'brug and bSam yas Bells stand in contrast to Korean temple bells, which are hung close to the ground (see above). They were hung even higher than Chinese temple bells, which are designed to be hit on their striking points and thus hung with their middles at around chest height. Yet we cannot be sure about the original 


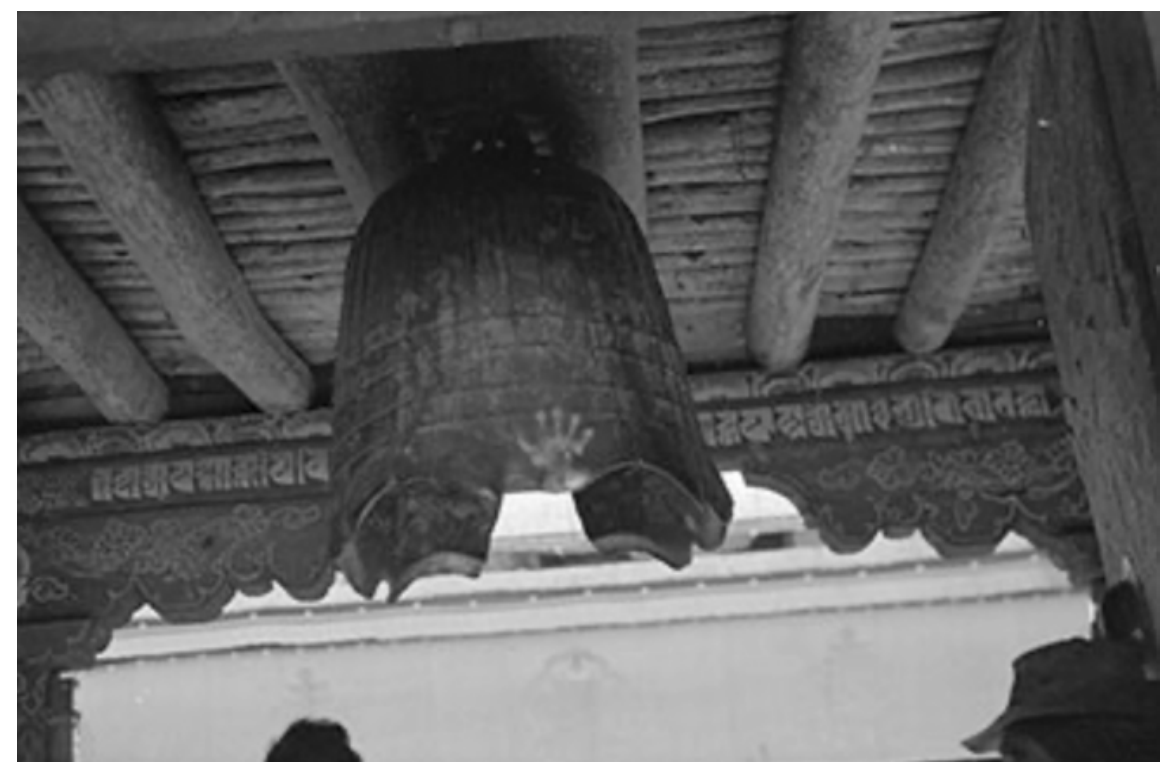

Figure 15: The Khra 'brug Bell in the Tibet Album, 2001.59.13.48.1; http://web.prm.oxac.uk/ tibet/photo_2001.59.13.48.1.html.

hanging position of any of these bells (or, indeed, at what time and in what context the Khra 'brug Bell gained that handprint visible in Figure 15 on its bent scallop-point, opposite the missing one).

The bell possesses more ribs, both vertical and horizontal, than the bSam yas Bell - making more of a geometric pattern than a mere paneling effect. Richardson reports that it "is larger than that at Bsam-yas but less graceful, and part of it has been broken off." 56 One of those six scallops is missing and another is little bent, but they appear to splay out at the bottom, unlike the bSam yas Bell. The epigraphy, though, is likewise high up on the body of the bell and broken up by the ribbing into twelve segments that run in two lines around the bell from left to right.

Again, like the bSam yas Bell, the inscription shows Old Tibetan characteristics. Although it is slightly more damaged than the bSam yas Bell inscription, its readings were almost all clear enough to Richardson, who states that both "are votive offerings by royal persons in honour of Tibetan kings whose names are

56 Richardson, “A Ninth Century Inscription,” 166. See also Richardson, A Corpus of Early Tibetan Inscriptions, 82-83. 


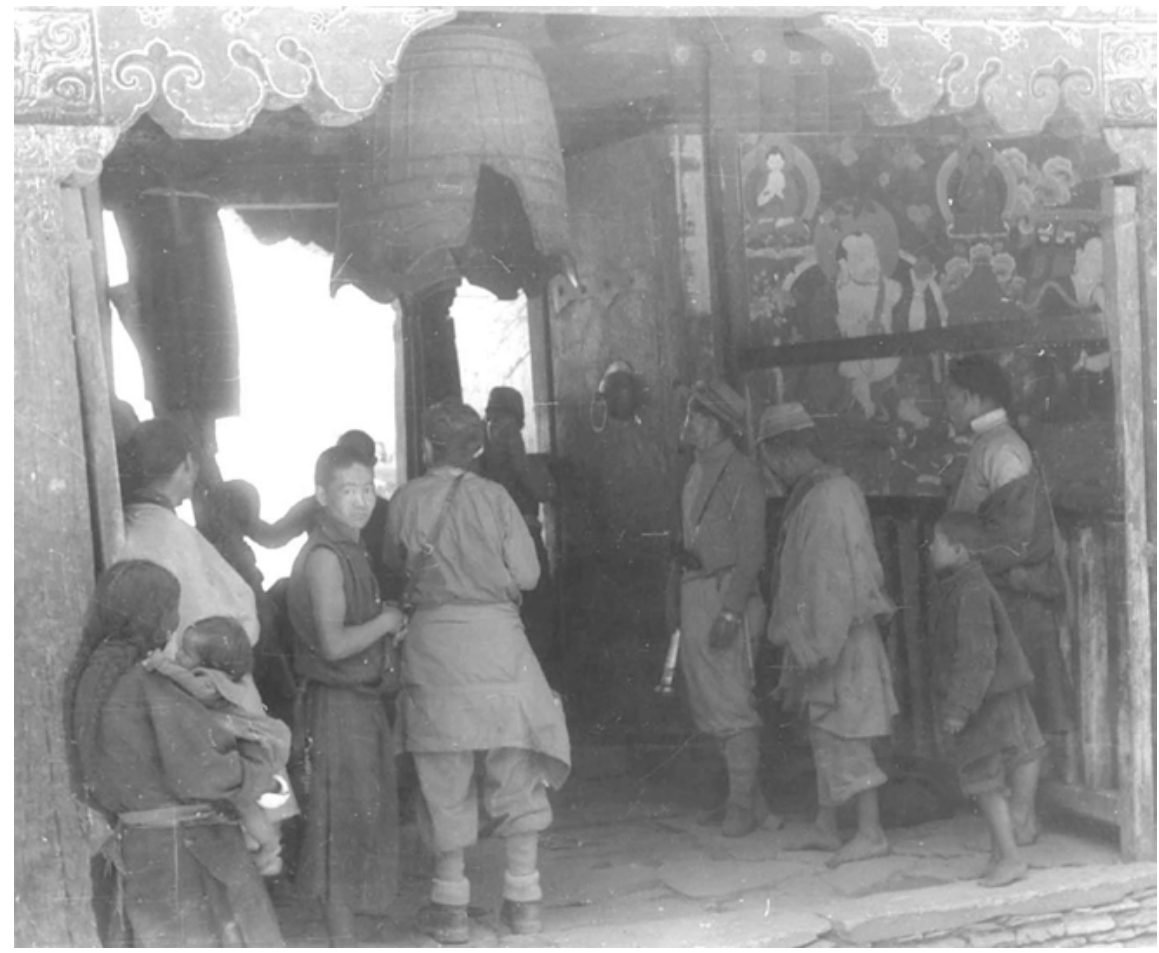

Figure 16: Giuseppe Tucci inspecting the Khra 'brug Bell, 1948; Per K. Sørensen, Guntrum Hazod, and Tsering Gyalbo, Thundering Falcon: An Inquiry into the History and Cult of Khra'Brug, Tibet's First Buddhist Temple (Vienna: Österreichischen Akademie der Wissenschaften, 2005), 161, fig. 92.

given in each case." ${ }^{57}$ The Khra 'brug Bell refers to its support as a dril chen po, in other words a "big bell," donated by Jo mo Byang chub ("Queen Enlightenment") for the sake of Emperor Khri lDe srong brtsan (r. ca. 800-815), the son of Khri Srong lde brtsan, as well as for gaining herself merit and encouraging all sentient beings to be virtuous. The inscription also says that the queen intended the bell to be "like the sound of the drum roll of the gods in the heavens" (lha"i rnga sgra bar snang la grag pa dang 'dra bar). The bell is also said to have been cast (lit. "poured," blugs) by the abbot/preceptor ( $m k$ khen po = mkhan po), the Chinese monk (rgya”i dge slong) named Rin cen (later rin chen; Skt. ratna; Ch. bao 寶). Therefore, not only do the scalloping, the ribbing, and the general proportions of

57 Richardson, A Corpus of Early Tibetan Inscriptions, 82. 
the Khra 'brug Bell suggest East Asian influence, but also the inscription identifies the founder as a Chinese Buddhist monk. Furthermore, the epigraphy appears to compare the bell (dril) with a drum ( $r n g a$ ), just as in China, the dharma bell (fanzhong) is sometimes called a dharma drum (fangu). ${ }^{58}$

The information given in this inscription has possible consequences for the bSam yas Bell also. Given the overwhelming similarity between the bSam yas and Khra brug Bells' proportions, scalloping, ribbing, and epigraphy, it appears that the Chinese-inspired term cong in the former is synonymous with the indigenous term dril chen po. Moreover, Jo mo Byang chub is thought to be none other than the ordination name of Khri Srong lde brtsan's queen, Jo mo rGyal mo brtsan. However, it seems that Khri lDe srong brtsan was not her son (or the son mentioned in the bSam yas Bell inscription?), but rather her stepson. ${ }^{59}$

There is an implication inherent in the identification of Queen Jo mo Byang chub with Queen Jo mo rGyal mo brtsan that Tibetan temple bells may have been getting bigger. If the queen of the bSam yas Bell inscription had been ordained by the time of the founding of the Khra 'brug Bell, and Richardson has stated that the latter is larger, this suggests that the smaller bSam yas Bell predates the bigger Khra 'brug Bell. We may then add to that the possible evidence of the dPa' ris Bell: if it is genuinely older than both the bSam yas and Khra 'brug Bells, and of the smallest measurements, this would suggest that Tibetan imperial temple bells were becoming successively larger in size (though keeping roughly the same proportions) over the eighth century and into the ninth century. Perhaps the very similar bSam yas Bell was "poured" by the same monk, Rin c(h)en, or another Chinese mkhan po/dge slong, who may have gained the ability to cast bigger bells and so not only create more religious merit for the donors but also show off their cosmopolitanism by commissioning examples of this marvelous East Asian technology. As Richardson suggests,

The making of such large bells was a considerable undertaking and although the Tibetans had a reputation as metal workers there is no evidence that they had acquired by that time the art of metal casting. According to later tradition Chinese craftsmen were employed on the decoration of Bsam-yas. A Chinese monk supervised the casting of the Khra-'brug bell at the beginning of the 9th century. Chinese monks had been invited to Tibet in 781 A.D. according to the Tse (sic) Fu Yuan Kuei [the Song-dynasty encyclopaedia titled Cefu Yuangui 冊府元龜] and it is possible that one of them, perhaps the same one

58 See Paul W. Kroll, Dharma Bell and Dhāraṇi Pillar: Li Po’s Buddhist Inscriptions (Kyoto: Scuola Italiana di Studi sull'Asia Orientale/Italian School of East Asian Studies, 2001), 18.

59 Richardson, A Corpus of Early Tibetan Inscriptions, 32; Li and Coblin, A Study of the Old Tibetan Inscriptions, 338, n. 1; 341; 346, n. 10. See also Sørensen, Hazod, and Tsering Gyalbo, Thundering Falcon, 160-61, n. 5. 
who cast the Khra-'brug bell, was commissioned by the queen to make that at Bsam-yas with its unmistakably Chinese shape. ${ }^{60}$

This Rin cen could be a monk of a Chinese Chan Buddhist school, if the queen's attributed links to this school are to be believed. ${ }^{61}$ It is uncertain whether the bells were found in Tibet by an artisan who knew the art of bronze casting from the east, or made elsewhere (in collaboration with someone who knew the Tibetan script for the written epigraphy) and then brought to central Tibet. Intriguingly, Per K. Sørensen, Guntrum Hazod, and Tsering Gyalbo identify a place near Khra 'brug and in the Yar klung valley of the emperors that is today named Cong (i.e. "bell"). ${ }^{62}$ Thus, as they suggest, the raw materials may have been excavated from this place, whereas another possibility is that this was the site of a Tibetan imperial bell foundry.

\section{The Yer pa Bell}

The Yer pa Bell was thought to be no longer extant, like the Khra 'brug Bell, but has recently reappeared at the Dunhuang Academy in Gansu Province. Until more research can be carried out on it, we must rely on the photographs of Richardson (Figure 17) and Heinrich Harrer (Figure 18). ${ }^{63}$ These show its body design to consist of vertical and horizontal ribs forming the inscription panels and perhaps a lower horizontal band, most closely resembling the bSam yas Bell. Its scallops seem quite solid and tend to bend inwards, like those of the bSam yas Bell, rather than splay out like those of the Khra 'brug Bell. Yet the scallops appear to be more pointed than either of the above two Tibetan bells. Beading has been cast into the bell at the top, above the inscription panels, as is also found in the Bumthang Bell (below) but not in the above Tibetan examples. There may be some ornamentation below the panels, but it is unclear

60 Richardson, A Corpus of Early Tibetan Inscriptions, 82.

61 See the discussion of slightly later sources on Jo mo Byang chub in Paul Demiéville, Le Concile de Lhasa: Une controverse sur le quiétisme entre Bouddhistes de l'Inde et de la Chine au VIIIe. siècle de l'ère chrétienne (Paris: Presses Universitaires de France, 1952), 25-33; Richardson, A Corpus of Early Tibetan Inscriptions, 33; Li and Coblin, A Study of the Old Tibetan Inscriptions, 338. Sørensen, Hazod, and Tsering Gyalbo, Thundering Falcon, 161, n. 6, speculate on his possible identification with other Rin chens known as monks or monkartisans during the Tibetan imperial period.

62 Sørensen, Hazod, and Tsering Gyalbo, Thundering Falcon, 161, n. 7; 250; 114, sat-map 2.

63 The Yer pa Bell's condition is also "lost" according to Iwao et al., Old Tibetan Inscriptions, 72. 


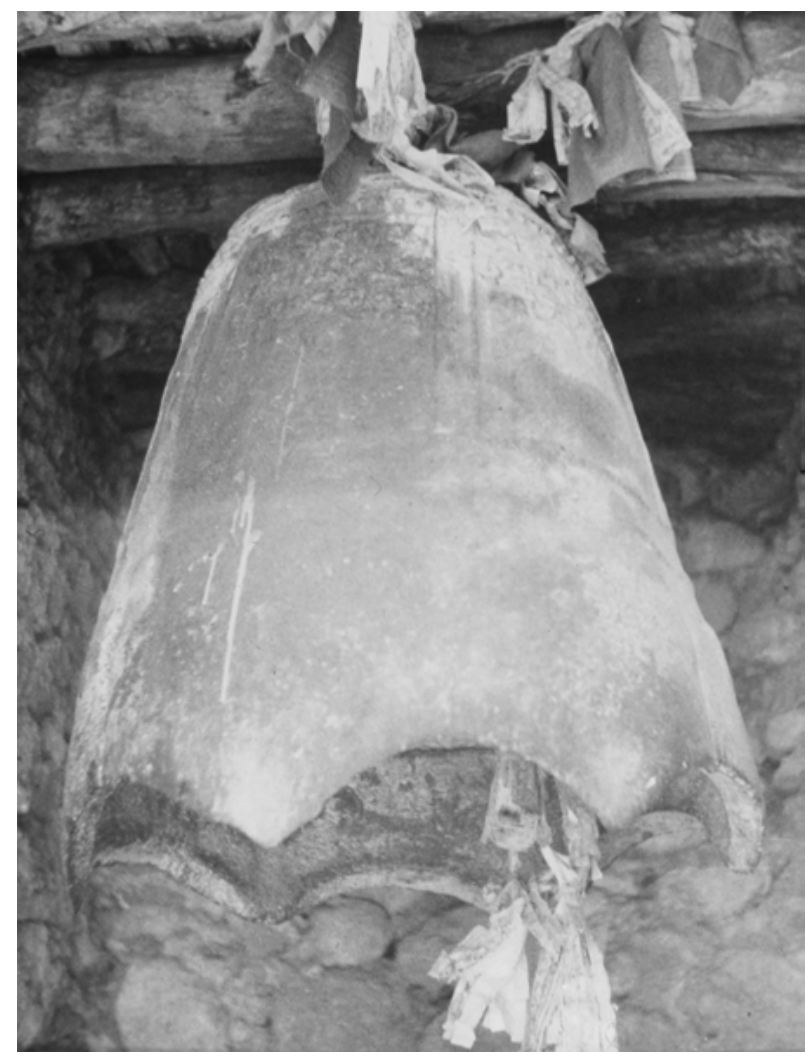

Figure 17: Photograph of the Yer pa Bell in the Tibet Album, 2001.59.2.44.1; http://web.prm. ox.ac.uk/tibet/photo_2001.59.2.44.1.html.

from the photographs. The inscriptions positioned at the top of the bell across four panels comprise two prayers in an Indic and Tibetan script, respectively. Unlike the bell inscriptions above, both prayers are ritual rather than commemorative and contain no reference to imperial people or places. ${ }^{64}$

The inscription is again written on the upper part of the bell, as in the above examples. However, unlike the epigraphy on the bSam yas and Khra 'brug Bells, the Yer pa Bell's inscription is arranged in four panels rather than six that are to be read from right to left. Although the actual content of the epigraphy is taken from the prayer genre, and so offers no direct proof of an imperial date, the style

64 Richardson, “A Ninth Century Inscription,” 166. 


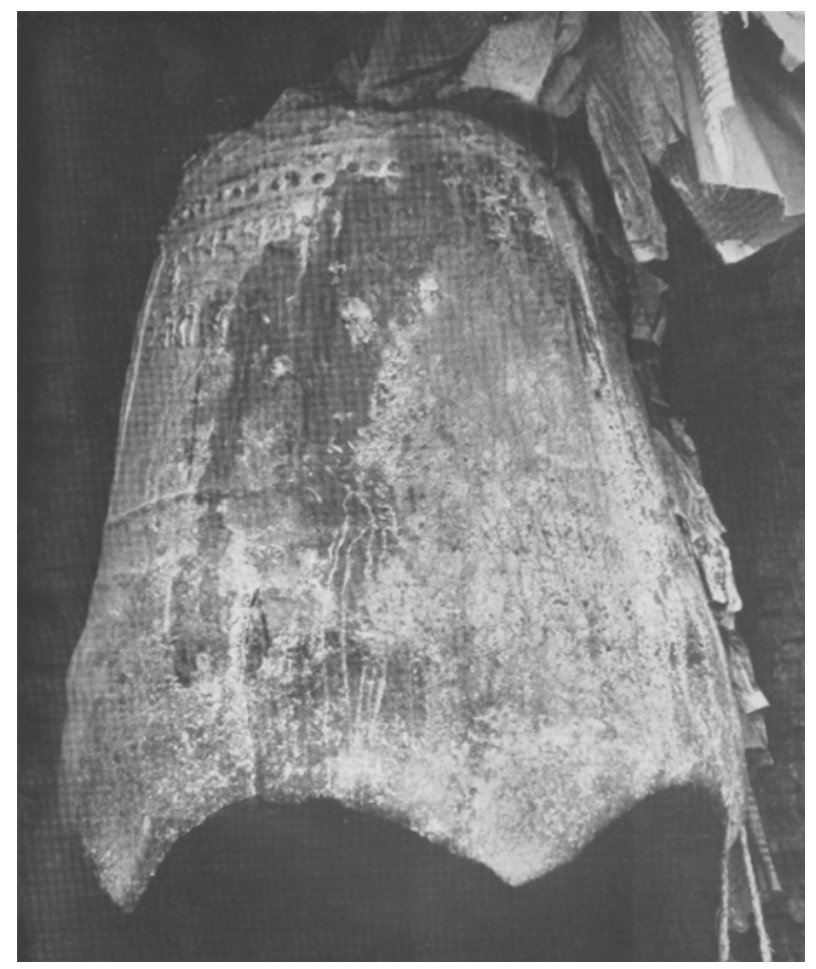

Figure 18: The Yer pa Bell in Heinrich Harrer, and Heinz Woltereck, Meine Tibet-Bilder (Seebruck am Chiemsee: Heering-Verlag, 1953), 65.

of the bell itself is similar to the those above, and the paleography and orthography of its inscription (which is molded into the bell) suggest that it was founded in the eighth or ninth century. ${ }^{65}$ One of the collaborators would have had to have known not only Tibetan script but also an Indic script and the prayer written in that language, suggesting once again the close involvement of a monk or abbot.

\section{The Bumthang Bell}

Finally, mention should be made of a cong bell incorporating Tibetan epigraphy, housed in the small temple of dKon mchog gsum in Bumthang in Bhutan, of which Michael Aris has published a photograph and short contextualization

65 Richardson, A Corpus of Early Tibetan Inscriptions, 144. 
(Figure 19). ${ }^{66}$ He states that the temple is small for Bhutanese religious edifices, which along with other indicators may suggest its link to Buddhism during the Tibetan imperial period. No other such ancient artifacts exist in this region, and so Aris suggests, "The bell thus carries great potential significance for the early history of the area: if the cong can be shown to belong to the temple where it is

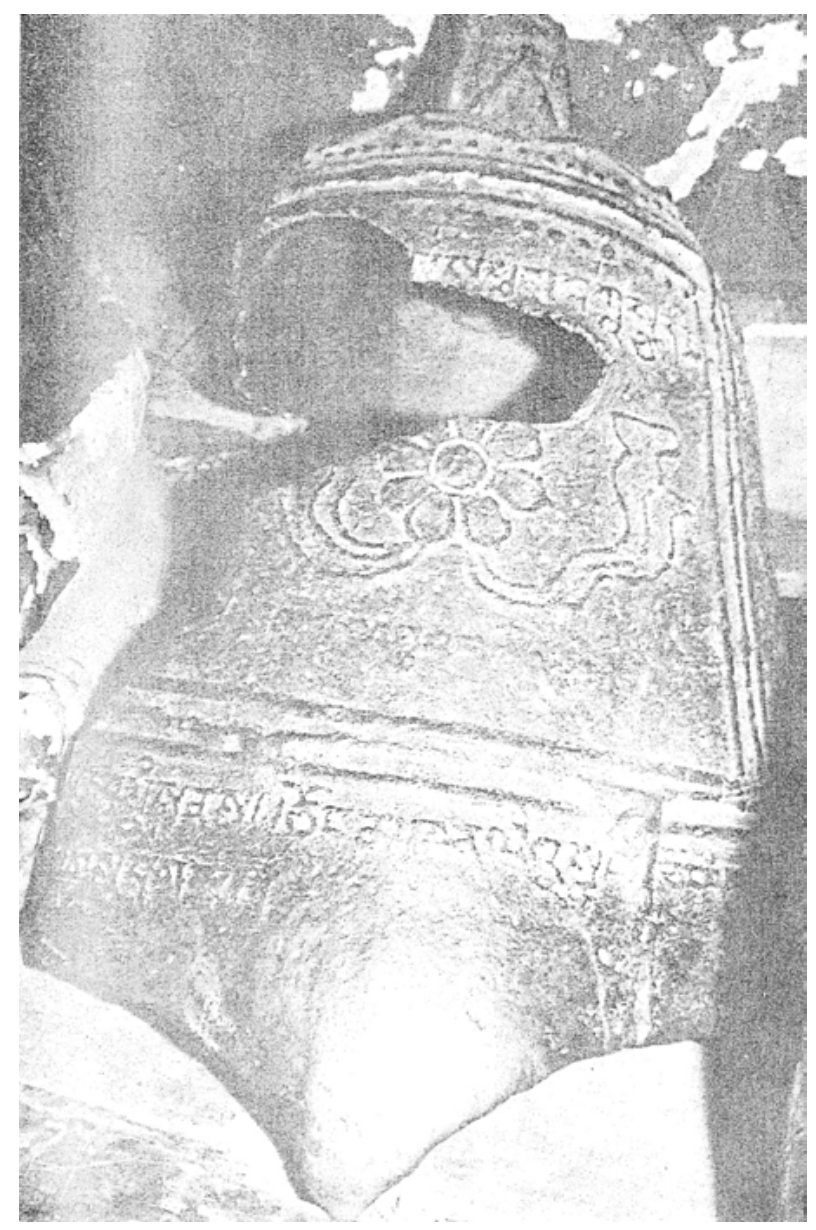

Figure 19: The Bumthang Bell in Michael Aris, Bhutan: The Early History of a Himalayan Kingdom (Warminster: Aris \& Phillips, 1979), plate 6.

66 Aris, Bhutan, 33-38 and plate 6. 
now found it would be the single and indisputable relic of Tibetan missionary activity south of the Himalayas in this early period." ${ }^{67}$ As he freely admits, though, even large temple bells are ultimately mobile and so this exemplar could have been brought to Bhutan after the Tibetan empire fell.

The bell is broken, and only the largest part of it is extant. However, the general outline is still recognizable, which Aris in his earlier PhD thesis describes as similar to the other imperial temple bells and a certain Chinese model: "all the later temple bells of China belonging to this type preserve the characteristic shape and features of these bells in Tibet: side panels divided by vertical ribbing and an 'undulating' lower edge (most pronounced in our example here)."68

As Aris rightly notes, the scalloping is markedly pronounced in this example. The bell is scalloped in a concave way with sharp points at the nadirs, but with fewer scallops than any of the bells above, perhaps only four. It also appears, from this image at least, to possess a much wider bottom than top (more "A-shaped" than the bells above), though we again lack any measurements or other indications of the proportions of this bell. Uniquely among the Tibetan bells, it possesses a striking point consisting of an eight-petalled lotus and banner design. The striking point is too high up the bell to be a safe means of ringing it, and so would presumably have been intended as a purely decorative design feature. If it was used as a striking point, however, perhaps this was responsible for the cracking of the bell.

Like the Yer pa Bell, this Bumthang Bell is divided into large panels, delineated by ribbing, but with one extra set of horizontal and vertical ribs forming an enclosing frame around the panels. The shoulder of this bell above the written epigraphy is lined with horizontal beading, also like the Yer pa Bell (but in this case two rows of beading, one within the panel and one above the top horizontal band). The Bumthang Bell also seems to include both an Indic and Tibetan inscription. The Indic part at the top is in Tibetan transcription, however, and placed above the Tibetan, one that is molded much lower down the bell than any of the above examples. The form of the bell is thus more complex than that of the Yer pa Bell, and so may postdate it. Among the details of the Tibetan inscription that Aris has recorded, including terms such as byang chub, "enlightenment," is the statement that the bell was cast by the bell founder

67 Aris, Bhutan, 36.

68 Michael Aris, "A Study on the Historical Foundations of Bhutan: With a Critical Edition and Translation of Certain Texts in Tibetan" (PhD diss., School of Oriental and African Studies, University of London, 1978), 79-80. 
(cong mkhan, lit. “one knowledgeable about congs”) named Li'u sTa(n)g (cong mkhan li'u sta(n)g cong bya [. . . ] blugs). ${ }^{69}$ This suggests that an expert or specialist in bell founding - with a Chinese ethnonym or patronym, but lacking a name such as Rin chen, reminiscent of an ordained monk or abbot ${ }^{70}-$ was brought to Bhutan, if indeed this is where the bell was cast and not elsewhere (in central Tibet and merely carried here). Thus, Aris is correct that the Bumthang Bell is similar to some temple bells of China, and a Chinese artisan is apparently credited with its founding. However, the design, scalloping, and epigraphy of this bell are quite dissimilar to the Tibetan imperial model of the bSam yas and Khra 'brug bells. The Yer pa Bell stands somewhere between these two types, whereas the more rounded $\mathrm{dPa}$ ' ris Bell stands at the other extreme altogether. This may conform to a possible chronological order of the Tibetan imperial bells that begins with the small and squat dPa' ris Bell (with its rounded scallops) and runs through the taller bSam yas, Khra 'brug, and Yer pa Bells, ending with the more A-shaped Bumthang Bell (with its pointed scalloping).

\section{Conclusion}

We unfortunately do not possess all of the exemplars of temple bells of Tibet or the countries surrounding it. Far from it, in fact, given that each monastery may have had its own bell and that new monasteries would have appeared in many of the areas into which Buddhism spread - and so inscribed bells surely spread with the religion. Nevertheless, those exemplars that remain allow us to draw some conclusions about the early design(s) of temple bells in comparison with examples from East and Southeast Asia. The extant Tibetan imperial temple bells are all convex, as opposed to bell 3 in Figure 1, above. Yet in all other ways, they follow this simpler Chinese model most closely. All except the Bumthang Bell lack complex ornamentation and a striking point. All except the $\mathrm{dPa}$ ' ris Bell use horizontal and vertical ribbing in their designs. These ribs help form panels into which the epigraphy is cast rather than inscribed (unlike the earliest Chinese and Vietnamese examples above). Further, there is a marked tendency (excluding the dPa' ris Bell) to place the written epigraphy in the top half of the bell (though inscriptions below can be made in addition) - in contrast to the Jingyun and Sŏngdŏk Bells. Including Tibetan script in the mold must have been a difficult undertaking, but it is very well realized (again

69 Aris, Bhutan, 34.

70 See Aris, "A Study on the Historical Foundations of Bhutan," 80-82; Aris, Bhutan, 36. 
excluding the supposedly early dPa' ris Bell), even if this means that some syllables are split across the panels, as in the bSam yas Bell.

With respect to the scalloping specifically, examples from China, Korea, Vietnam, and Japan may all once again prove instructive. The scalloped bell seems to be the only form of temple bell cast in imperial Tibet, but it is neither the only option available nor a homogenous type either in China or elsewhere in Buddhist Asia. Thus, a number of decisions appear to have been made during the Tibetan imperial period with regard to the scalloping: first, whether to scallop the bell; second, with how many "petals" or points; and third, to what extent. The first question was seemingly always answered in the affirmative. The second has led in all cases except the Bumthang Bell to a six-scalloped mouth, which outside of Tibet is also the standard (excepting the later Japanese example in Figure 7). This is despite the fact the most lotuses in other aspects of the bells' design have eight petals. It is in answering the third question that we find the most variety.

Perhaps a useful distinction can be made between concave, convex, and "undulating curve" scalloping in all these Tibetan bells as well as in their East Asian contemporaries and antecedents. The concave type is where, if the bell were laid on its rim, it would rest on small points (and, in theory, be least stable); the convex type would rest on the majority-flat rim (and be most stable); and the undulating wave bell would rest on rounded scallops or slightly flattened circular edges. Most of the bells surveyed above are of the concave variety. The Japanese bell in Figure 6 is of the convex type. Of the Tibetan examples, the Yer pa and Bumthang Bells definitely rest on their points, with the latter being especially pointed. The others have undulating scallops, perhaps even tending toward the convex in that they have more flattened mouths; yet none reach the convex extreme of the Japanese exemplar (Figure 6). This tentative typology may be worth expanding through future research in order to incorporate Tibetan imperial temple bells into an East (and Southeast) Asian typology. Comparing how the technology entered each area, and how each region's types of bell differ from each other in their relative rarity or divergent design, can illuminate the decisions taken by artisans and patrons during the Tibetan imperial period.

This can help reframe the Tibetan temple bell as art rather than merely the bearer of a text mined for its historical value alone. Contextualizing Tibetan imperial temple bells within a wider aesthetic context would also aid the wider study of temple bells in Buddhist Asia, since the Tibetan examples reviewed above seem to rank among the earliest extant exemplars of the form. Such a comparative approach to temple bells could complement similar studies of other examples of eighth- and ninth-century Tibetan imperial material culture, 
where the flows of technology may prove to be the same. That is why there are still wide vistas opening up beyond the text in Buddhist Asia.

\section{Bibliography}

An Xu (安旭). “Xizang Sangyuan si zhudian bihua lüekao 西藏桑鳥寺主殿壁畫略考 [Notes on the wall paintings in the main hall of Sang Yuan Temple Xizang (Tibet)]. Wenwu 文物 [Cultural relics] no. 8 (1982): 1-6.

Aris, Michael. "A Study on the Historical Foundations of Bhutan: With a Critical Edition and Translation of Certain Texts in Tibetan.” PhD diss., School of Oriental and African Studies, University of London, 1978.

Aris, Michael. Bhutan: The Early History of a Himalayan Kingdom. Warminster: Aris \& Phillips, 1979.

Beckwith, Christopher I. The Tibetan Empire in Central Asia: A History of the Struggle for Great Power among Tibetans, Turks, Arabs, and Chinese During the Early Middle Ages. Princeton: Princeton University Press, 1987.

Cable, E. M. “Old Korean Bells.” Royal Asiatic Society Korea Branch 16, no. 1 (1925): 1-45.

Ch’oe Ǔng-ch’ŏn, and Kim Yŏn-su. Kŭmsok Kongye. Seoul: Sol, 2004.

Chŏng, Yŏng-ho, and Hae-b̌om Yi. Kŭmsok Kongye. Ch'op’an. Seoul: Chungang Ilbosa, 1985.

Demiéville, Paul. Le Concile de Lhasa: Une controverse sur le quiétisme entre Bouddhistes de l'Inde et de la Chine au VIIle. siècle de l'ère chrétienne. Paris: Presses Universitaires de France, 1952.

IHa mchog skyabs (兰却加). “Btsan po khri lde btsug brtsan skabs kyi jag rog dga’ Idan byin chen gtsug lag khang gi dril bu'i kha byang gi yi ger dpyad pa” [Remarks on the text of a bell of the Jag rog dga' Idan byin chen sanctuary from the time of Emperor Khri IDe btsug brtsan]. Bod ljongs zhib 'jug/西藏研究/Tibetan Studies 1 (2011): 1-9.

Hanŭl Kkotŭro Naerinŭn Kkaedarŭmŭi Sori. Kimchun: Chikchi sŏngbo Pangmulgwan, 2003.

Harrer, Heinrich, and Heinz Woltereck. Meine Tibet-Bilder. Seebruck am Chiemsee: HeeringVerlag, 1953.

Hashizume Kinkichi (橋爪金吉), and Asano Kiichi (浅野喜市). Bonshō Junrei 梵鐘巡礼. Tokyo: Bijinesukyōikushuppansha ビジネス教育出版社, 1976.

Heissig, Walther. The Religions of Mongolia. Trans. Geoffrey Samuel. Berkeley: University of California Press, 1980.

Hulbert, Homer B. "The Great Bell.” The Korea Review 2 (1902): 387.

Iwao Kazushi (岩尾一史) et al. Old Tibetan Inscriptions: Old Tibetan Documents Online Monograph Series II. Tokyo: Research Institute for Languages and Cultures of Asia and Africa, Tokyo University of Foreign Studies, 2009.

'Jam dbyangs (甲央), and Wang Mingxing (王明星). Baozang 寶藏 [Precious deposits: Historical relics of Tibet, China]. Beijing: Chaohua chubanshe 朝華出版社, 2000.

Киселев [Kiselev], С. В. Древняя история Южной Сибири [Drevniaia istoriia iuzhno i Sibiri]. Moscow: Изд-во Академии наук СCCP [Izd-vo Akademii nauk USSR], 1951.

Kroll, Paul W. Dharma Bell and Dhāraṇi Pillar: Li Po's Buddhist Inscriptions. Kyoto: Scuola Italiana di Studi sull'Asia Orientale/Italian School of East Asian Studies, 2001.

Kungnip Kyŏngju Pangmulgwan. Sŏngdǒk Taewang Sinjong. Gyeongju: Kungnip Kyŏngju Pangmulgwan, 1999. 
Kungnip Munhwajae Yŏn'guso, and Ko Sŭng-gwan. Chuch ǒlchang: Chungyo Muhyŏng Munhwajae 112-ho. Daejeon: P'ia, 2006.

Lee Ho-Kwan. "A Study on the Temple Bell Style in the Koryo Style.” In Koryŏ Sidae Pŏmjong Yangsik Ui Yŏn'gu, edited by Yi Ho-gwan, 189-193. Seoul: Tanguk Taehakkyo, 1976.

Li Fang-Kuei, and W. South Coblin. A Study of the Old Tibetan Inscriptions. Taipei: Institute of History and Philology, Academica Sinica, 1987.

Nicolas, Arsenio. "Gongs, Bells and Cymbals: The Archaeological Record in Maritime Asia from the Ninth to the Seventeenth Centuries." Yearbook for Traditional Music 41 (2009): 62-93.

Nihon no bijutsu 日本の美術 [Art of Japan], no. 355 (1995).

Price, Percival. Bells and Man. Oxford: Oxford University Press, 1983.

Richardson, Hugh Edward. "A Ninth Century Inscription from Rkon po." Journal of the Royal Asiatic Society 3-4 (1954): 157-73.

Richardson, Hugh Edward. A Corpus of Early Tibetan Inscriptions. London: Royal Asiatic Society, 1985.

Salmon, Claudine. "A Tentative Interpretation of the Chinese Inscription (1231) Engraved on a Bronze Gong Recovered in Muara Jambi (Central Sumatra).” Archipel 66 (2003): 91-112.

Salmon, Claudine. "Tang-Viet Society as Reflected in a Buddhist Bell Inscription from the Protectorate of Annam (798)." In Guangdong: Archaeology and Early Texts/Archäeologie und frühe Texte (Zhou-Tang), edited by Shing Müller, Thomas 0. Höllemann, and Putao Gui, 195-216. Wiesbaden: Harrassowitz, 2004.

Salmon, Claudine. "Transnational Networks as Reflected in Epigraphy: The Case of Chinese Buddhist Bells in Southeast Asia." In Chinese Overseas: Migration, Research and Documentation, edited by Tan Chee-Beng and Julia Zimmerman, 23-84. Sha tin, N.T, Hong Kong: The Chinese University Press, 2007.

Sørensen, Per K., Guntrum Hazod, and Tsering Gyalbo. Thundering Falcon: An Inquiry into the History and Cult of Khra-'Brug, Tibet's First Buddhist Temple. Vienna: Österreichischen Akademie der Wissenschaften, 2005.

Tsuboi Ryōhei (坪井良平). Bonshō No Kenkyū 梵鐘の研究 [A study of the bell]. Tokyo: Bijinesu Kyōiku Shuppansha ビジ ス 教育出版社, 1991.

Tucci, Giuseppe. The Tombs of the Tibetan Kings. Roma: Is.M.E.0, 1950.

Tucci, Giuseppe, and Walther Heissig. Die Religionen Tibets und der Mongolei. Stuttgart: Kohlhammer, 1970.

Walter, Michael L. Buddhism and Empire: The Political and Religious Culture of Early Tibet. Leiden: Brill, 2009.

Yi Ho-gwan. Koryŏ Sidae Pŏmjong Yangsik Ǔi Yŏn'gu. Seoul: Tanguk Taehakkyo, 1976.

Yŏm, Yŏng-ha. Han'guk Ǔi Chong: Korean Bell. Seoul: Seoul Taehakkyo Ch'ulp'anbu, 1991.

Yŏm Yŏng-ha, and Hanguk Chŏngsin Munhwa Yǒnguwŏn. Hanguk Chong Yǒngu. Seongnam: Hanguk Chŏngsin Munhwa Yŏnguwŏn, 1984. 